\title{
REVIEWS
}

\section{Rituximab therapy in nephrotic syndrome: implications for patients' management}

\author{
Aditi Sinha and Arvind Bagga
}

\begin{abstract}
Rituximab offers an alternative to current immunosuppressive therapies for difficult-to-treat nephrotic syndrome. The best outcomes are seen in patients with steroid-dependent nephrotic syndrome who have failed to respond to multiple therapies. By contrast, the benefits of rituximab therapy are limited in patients with steroid-resistant nephrotic syndrome, particularly those with focal segmental glomerulosclerosis (FSGS). Therapy with plasma exchange and one or two doses of rituximab has shown success in patients with recurrent FSGS. Young patients and those with normal serum albumin at recurrence of nephrotic syndrome are most likely to respond to rituximab therapy. A substantial proportion of rituximab-treated patients with idiopathic membranous nephropathy show complete or partial remission of proteinuria, and reduced levels of phospholipase $\mathrm{A}_{2}$ receptor autoantibodies, which are implicated in the pathogenesis of this disorder. Successful rituximab therapy induces prolonged remission and enables discontinuation of other medications without substantially increasing the risk of infections and other serious adverse events. However, the available evidence of efficacy of rituximab therapy is derived chiefly from small case series and requires confirmation in prospective, randomized, controlled studies that define the indications for use and predictors of response to this therapy.
\end{abstract}

Sinha, A. \& Bagga, A. Nat. Rev. Nephrol. 9, 154-169 (2013); published online 22 January 2013; doi:10.1038/nrneph.2012.289

\section{Introduction}

Rituximab is a chimaeric monoclonal antibody against CD20, an antigen expressed during most stages of B-cell development. Binding of rituximab to $\mathrm{CD} 20$ causes rapid depletion of B-cell populations and has been used for the treatment of a number of autoimmune disorders. ${ }^{1}$ This agent is approved for therapy in non-Hodgkin lymphoma, chronic lymphocytic leukaemia, vasculitis and rheumatoid arthritis. ${ }^{2,3}$ In addition, rituximab has been tested in clinical trials for the treatment of systemic lupus erythematosus, and is used off-label for post-transplant lymphoproliferative disease. ${ }^{2}$ Rituximab has also been used in the treatment of patients with nephrotic syndrome, including those with steroid-dependent nephrotic syndrome or steroid-resistant nephrotic syndrome, recurrent focal segmental glomerulosclerosis (FSGS) and membranous nephropathy (Box 1). ${ }^{4-7}$

This Review provides an overview of the available data on the safety and efficacy of rituximab in the treatment of paediatric and adult patients with nephrotic syndrome. Most reports are anecdotal or limited to case series, as limited data on the efficacy and safety of this treatment are available from prospective controlled trials. Owing to the retrospective nature of these reports, the indications for rituximab administration to patients are unclear and definitions of response are heterogeneous. Accordingly, we have reviewed studies on the efficacy of rituximab in patients with steroid-resistant

Competing interests

The authors declare no competing interests. nephrotic syndrome, recurrent FSGS or membranous nephropathy, in which achievement of complete or partial remission is reported on the basis of standard definitions, or by the authors of individual studies. ${ }^{8-10}$ For patients with steroid-dependent nephrotic syndrome, we have reviewed studies in which the frequency of relapses, the use of corticosteroids and other immunosuppressive agents and the need for re-treatment with rituximab was reported.

\section{Mechanisms of action}

CD20 is a calcium-channel protein expressed in B cells during maturation, in precursor $\mathrm{B}$ cells and mature $\mathrm{B}$ cells, but not in plasma cells. ${ }^{11}$ Although the function of CD20 is not clear, binding of rituximab or other antiCD20 monoclonal antibodies to this ligand in vitro activates apoptosis via complement-dependent cytotoxicity and antibody-dependent cytotoxicity, which leads to rapid depletion of $\mathrm{B}$ cells. ${ }^{11,12} \mathrm{After}$ binding to rituximab, $\mathrm{CD} 20$ is translocated into lipid rafts, where signalling through tyrosine kinases, mitogen-activated protein kinases and phospholipase $\mathrm{C} \gamma$ mediates inhibition of B-cell growth or leads to apoptosis. ${ }^{12-14}$

The mechanisms by which rituximab induces remission in patients with nephrotic syndrome are unclear (Figure 1). Proteinuria in patients with minimal change disease and FSGS might be mediated by unrecognized permeability factor(s), perhaps a T-cell cytokine. ${ }^{15}$ Since $B$ cells activate T-helper cells through antigen presentation, depletion of B cells might alter T-cell function or 
subpopulation expansion. ${ }^{16}$ Alternatively, the beneficial effects of rituximab therapy in patients with nephrotic syndrome might be mediated through restoration of T-regulatory $\left(\mathrm{T}_{\mathrm{REG}}\right.$ ) cell populations and/or upregulation of their functions, similar to changes seen in patients with idiopathic thrombocytopenic purpura, systemic lupus erythematosus and cryoglobulinaemic vasculitis. ${ }^{17-22}$ Another study showed that the proportion of B-regulatory $\left(\mathrm{B}_{\mathrm{REG}}\right)$ cells was increased during B-cell recovery in mice with autoimmune diabetes when they were given rituximab. Rituximab therapy may therefore induce $\mathrm{T}_{\mathrm{REG}}$ and $\mathrm{B}_{\mathrm{REG}}$ cell populations that restore immune tolerance. ${ }^{23}$

Several authors suggest that patients with nephrotic syndrome have deficient $\mathrm{T}_{\mathrm{REG}}$ cell function. ${ }^{24-28}$ In the 'two-hit' hypothesis of minimal change disease, proteinuria is initiated by podocyte expression of CD80, a T-cell co-stimulatory molecule. ${ }^{29}$ Persistent proteinuria might result from faulty cessation of CD80 expression, owing to impaired podocyte autoregulation or impaired production of soluble CTLA 4 by circulating $\mathrm{T}_{\mathrm{REG}}$ cells. After rituximab treatment, patients with membranous nephropathy have transiently increased numbers of $\mathrm{CD}^{+}$and $\mathrm{CD}^{+} \mathrm{T}$ cells, and a persistently increased number of natural killer cells, but no change in the number of $\mathrm{T}_{\mathrm{REG}}$ cells. ${ }^{30}$ However, two reports, currently published as abstracts, indicate that therapy with rituximab produces an absolute or relative increase in the number of $\mathrm{T}_{\text {REG }}$ cells. ${ }^{31,32}$

The rapidity with which rituximab reduces proteinuria in patients with idiopathic or recurrent FSGS suggests that this treatment has direct actions on the podocyte (Figure 1). The CD20-binding region of rituximab crossreacts with an amino acid sequence within acid sphingomyelinase-like phosphodiesterase $3 \mathrm{~b}$ (SMPDL3b). ${ }^{33}$ CD20 engagement by rituximab upregulates sphingomyelin phosphodiesterase (also known as acid sphingomyelinase) activity in B cells. ${ }^{34}$ The number of SMPDL $3 \mathrm{~b}^{+}$podocytes was lower in patients who developed recurrent FSGS after renal transplantation than in those who did not. ${ }^{35}$ Normal human podocytes incubated with sera from patients with recurrent FSGS showed downregulation of SMPDL3b, the presence of actin stress fibres and disruption of the cytoskeleton. These findings were attenuated or reversed in the presence of rituximab. ${ }^{35}$ Interestingly, in a podocyte model of HIV nephropathy, an altered actin cytoskeleton and diminished podocyte attachment were associated with decreased sphingomyelin phosphodiesterase activity. ${ }^{36}$ However, the role of this enzyme in the pathogenesis of FSGS requires confirmation in further studies.

Finally, patients with recurrent FSGS have high levels of soluble urokinase plasminogen activator surface receptor (uPAR) in serum. ${ }^{37}$ Experiments using transgenic mice and podocyte cultures show that sera from such patients activates podocyte UPAR and integrinlinked protein kinase, leading to foot process effacement, proteinuria and FSGS. Moreover, elevated serum levels of soluble UPAR are associated with a decrease in the number of $\mathrm{T}_{\mathrm{REG}}$ cells. ${ }^{38}$ The effect of rituximab on serum

\section{Key points}

- Therapy with rituximab induces and maintains remission effectively in patients with difficult-to-treat, steroid-dependent nephrotic syndrome; sustained remission enables the reduction of steroid doses and withdrawal of calcineurin inhibitors

- In patients with steroid-resistant nephrotic syndrome who fail to respond to treatment with calcineurin inhibitors, the response to rituximab therapy is less efficacious

- Rituximab dose(s), the rate of B-cell recovery and clinical response are not closely correlated

- Combined therapy with rituximab and plasma exchange might be useful to prevent or treat recurrence of focal segmental glomerulosclerosis

- Therapy with rituximab should be considered in patients with idiopathic membranous nephropathy who fail to respond to treatment with cyclophosphamide or calcineurin inhibitors

- Acute infusion reactions are frequent but transient in patients who receive rituximab; serious adverse effects, including an increased risk of infections, are uncommon

Box 1 | Definitions of disease status and response to therapy

\section{Nephrotic range proteinuria}

Adults: Proteinuria $>3.5 \mathrm{~g}$ per day.

Children: $>40 \mathrm{mg} / \mathrm{m}^{2}$ per hour; urinary protein:creatinine ratio $>2 \mathrm{mg} / \mathrm{mg}$ or $>200 \mathrm{mg} / \mathrm{mmol}$.

\section{Steroid-dependent nephrotic syndrome}

Two consecutive relapses while receiving predniso(lo)ne on alternate days, or within 15 days of its discontinuation.

\section{Steroid-resistant nephrotic syndrome}

Lack of remission despite 4-8 weeks of therapy with daily predniso(lo)ne at a dose of $60 \mathrm{mg} / \mathrm{m}^{2}$ or $2 \mathrm{mg} / \mathrm{kg}$ (maximum $60-80 \mathrm{mg}$ ) per day.

\section{CNI-dependent nephrotic syndrome}

Remission of steroid-dependent nephrotic syndrome is achieved during therapy with CNIs (tacrolimus or ciclosporin).

CNI-resistant and steroid-resistant nephrotic syndrome

No response to therapy with predniso(lo)ne as defined above, or to CNI therapy for 3-6 months.

\section{Complete remission}

Adults: Proteinuria $<0.3-1.0 \mathrm{~g}$ per day, normal serum albumin $(>30 \mathrm{~g} / \mathrm{l})$, and stable renal function.

Children: Urinary protein:creatinine ratio $<0.2-0.3 \mathrm{mg} / \mathrm{mg}$ or $<30 \mathrm{mg} / \mathrm{mmol}$ and normal serum albumin (>30 g/l).

\section{Partial remission}

Adults: Proteinuria $0.3-3.5 \mathrm{~g}$ per day and/or $\geq 50 \%$ decrease in proteinuria from baseline, and stable renal function.

Children: Urinary protein:creatinine ratio $0.2-2.0 \mathrm{mg} / \mathrm{mg}$ or $30-350 \mathrm{mg} / \mathrm{mmol}$; and serum albumin $>30 \mathrm{~g} / \mathrm{l}$.

Abbreviation: CNI, calcineurin inhibitor.

levels of soluble uPAR and activation of podocyte $\beta_{3}$ integrin is being examined in patients with FSGS. ${ }^{39}$ These findings need confirmation in large studies and across different populations.

\section{Determinants of treatment efficacy}

CD20 is internalized after binding to rituximab. Consequently, CD19 (another B-cell surface antigen) is used as a marker for reliable monitoring of B-cell numbers in rituximab-treated patients. ${ }^{40}$ Pharmacokinetic studies in patients with rheumatoid arthritis show that rituximab follows a two-compartment model with a terminal half-life of 19-22 days. ${ }^{41,42}$ The terminal 


\section{REVIEWS}

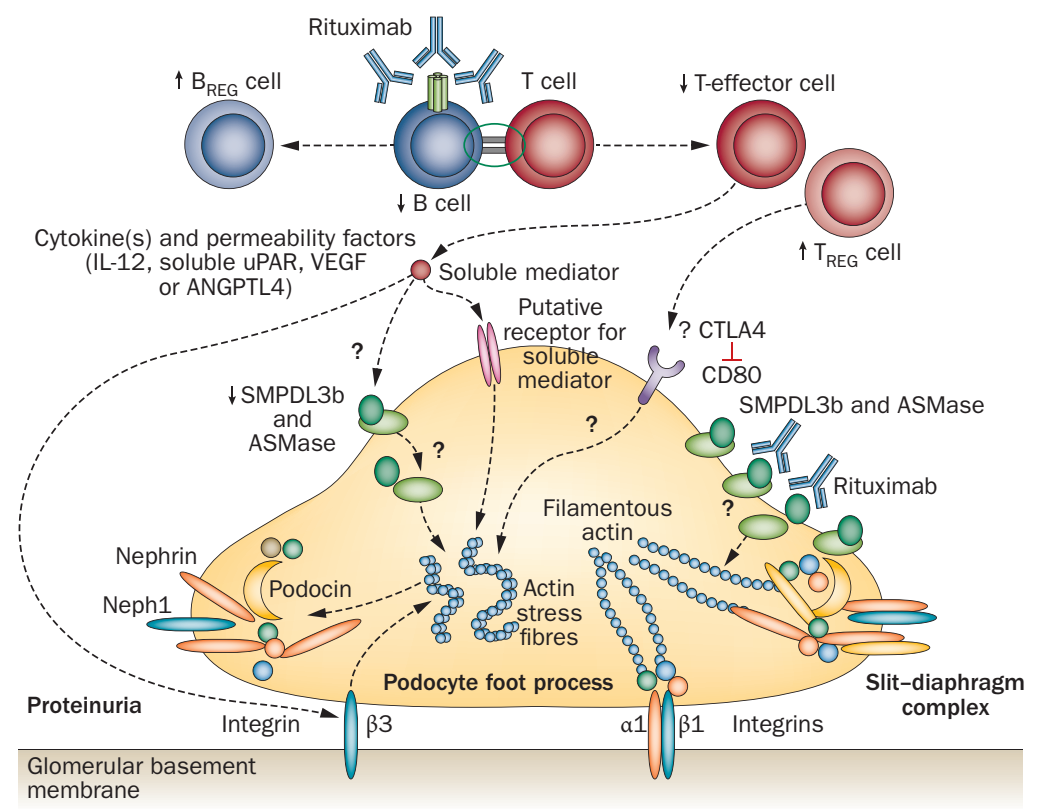

Figure 1 | Proposed mechanisms of action of rituximab in patients with nephrotic syndrome. B-cell depletion affects antigen presentation and activation of T cells through interaction with the T-cell receptor (circled in green), as well as inhibiting the production of cytokine(s) that might increase glomerular permeability. The role of rituximab in suppressing other permeability factors (for example, soluble UPAR, VEGF and ANGPTL4) is unclear. In an alternative model of minimal change disease, proteinuria is initiated by an increase in the expression of CD80 in podocytes. Production of CTLA4 by $T_{\text {REG }}$ cells, potentially enhanced by rituximab, might inhibit $\mathrm{CD} 80$ activation and reduce proteinuria. The role of $\mathrm{B}_{\mathrm{REG}}$ cells in mediating these effects is speculative. Finally, downregulation of SMPDL3b expression and loss of ASMase activity might lead to the formation of actin stress fibres, cytoskeletal disorganization and proteinuria, as shown in models of focal segmental glomerulosclerosis. Therapy with rituximab might reverse these changes. Abbreviations: ANGPTL4, angiopoietin-related protein 4; ASMase, acid sphingomyelinase; CTLA4, cytotoxic T-lymphocyte protein 4; REG, regulatory; SMPDL3b, sphingomyelin phosphodiesterase acid-like 3b; uPAR, urokinase plasminogen activator receptor; VEGF, vascular endothelial growth factor.

half-life of rituximab is 2.7 -fold longer after the fourth dose than after the first dose. ${ }^{43}$ Patients given four doses of rituximab also have a twofold higher serum level and prolonged serum half-life of the medication compared with patients who received a single dose. ${ }^{44-46}$

Prospective studies in patients with nephrotic syndrome show that one dose of rituximab results in profound B-cell depletion ( $<1 \%$ of leukocytes, or $0-5$ cells/ $\mathrm{mm}^{3}$ ) in $83.3-90.0 \%$ of patients, and that B-cell depletion lasts for 4-6 months after a single dose of rituximab. ${ }^{44,47}$ However, the relationships between the number of doses of rituximab and time to B-cell recovery, and between B-cell recovery and the occurrence of relapse of nephrotic syndrome have not been established. ${ }^{48,49} \mathrm{After}$ maximal B-cell depletion, which occurs by 2 weeks after therapy with two doses of rituximab, B cells start to reappear from week 16 onwards. ${ }^{42}$ In one study, all 19 patients who responded to rituximab therapy were in remission during B-cell depletion, and the patients who relapsed showed recovery of B cells to 3-7\% of leukocytes. ${ }^{48}$ Although the above finding has been confirmed in other studies, ${ }^{44,47}$ an equally important observation is that some patients have sustained remission despite B-cell recovery. ${ }^{44}$ In patients with rheumatoid arthritis, the timing of B-cell recovery bears no relation to the recurrence of symptoms. ${ }^{42}$ Similarly, in a nationwide survey of rituximab treatment for childhood-onset, difficult-to-treat nephrotic syndrome conducted in Japan, the time to B-cell recovery was similar in patients who relapsed compared with those in remission. ${ }^{50}$

The timing of re-treatment with rituximab is based on either the extent of B-cell recovery or the occurrence of one or more relapses. In one study, doses of rituximab were repeated in 12 of 19 patients who showed recovery of B cells after the initial clinical response. ${ }^{48}$ Others have used multiple courses of rituximab to achieve sustained B-cell depletion for 15-18 months in patients with steroid-dependent nephrotic syndrome. ${ }^{49,51}$ Prolonged B-cell depletion was associated with sustained remission for 2 years in two-thirds of patients, despite B-cell recovery, and without the use of additional immunosuppressive agents. ${ }^{51}$ Other research groups have successfully used re-treatment with rituximab to treat relapses. ${ }^{44,52,53}$

It is speculated that proteinuria in the nephrotic range might attenuate the biological effects of rituximab by causing increased urinary loss of the drug. ${ }^{48}$ Serum levels of rituximab were lower in patients with membranous nephropathy with substantial proteinuria than in those given rituximab during remission, or in patients with rheumatoid arthritis. ${ }^{30,45}$ Decreased efficacy of rituximab in patients with proteinuria in the nephrotic range has been proposed in other studies, ${ }^{48,53}$ which suggests that rituximab should be administered during remission. Although reduction of proteinuria by maximal inhibition of the renin-angiotensin-aldosterone axis might potentially reduce urinary losses of rituximab and increase its efficacy, this strategy requires prospective confirmation.

Most studies of patients with nephrotic syndrome have used a rituximab dose of $375 \mathrm{mg} / \mathrm{m}^{2}$ once a week for 1-4 weeks, which is adapted from the standard regimen for lymphoma. Serum levels of rituximab are similar irrespective of whether it is administered to children or adults, and whether doses of $375 \mathrm{mg} / \mathrm{m}^{2}$ or $1 \mathrm{~g} / \mathrm{m}^{2}$ are used. ${ }^{45}$ Evidence from case series suggests that remission is prolonged after therapy with 2-4 doses of rituximab; ${ }^{52,54,55}$ therefore, we propose that patients with nephrotic syndrome should receive two or more doses of this agent. Prospective studies are, however, required to examine the relationship between the number of rituximab doses and the chronology of B-cell recovery, and how this relationship affects the clinical response.

\section{Steroid-dependent nephrotic syndrome}

Approximately $40-60 \%$ of children with idiopathic nephrotic syndrome have frequent relapses or are dependent on steroid treatment. ${ }^{56}$ Although medications such as cyclophosphamide, levamisole and mycophenolate mofetil reduce the frequency of relapses in most patients, 57,58 the clinical management of some patients is difficult. Treatment with calcineurin inhibitors is effective, but is associated with considerable toxic effects 
Table 1 | The efficacy of rituximab in steroid-dependent nephrotic syndrome

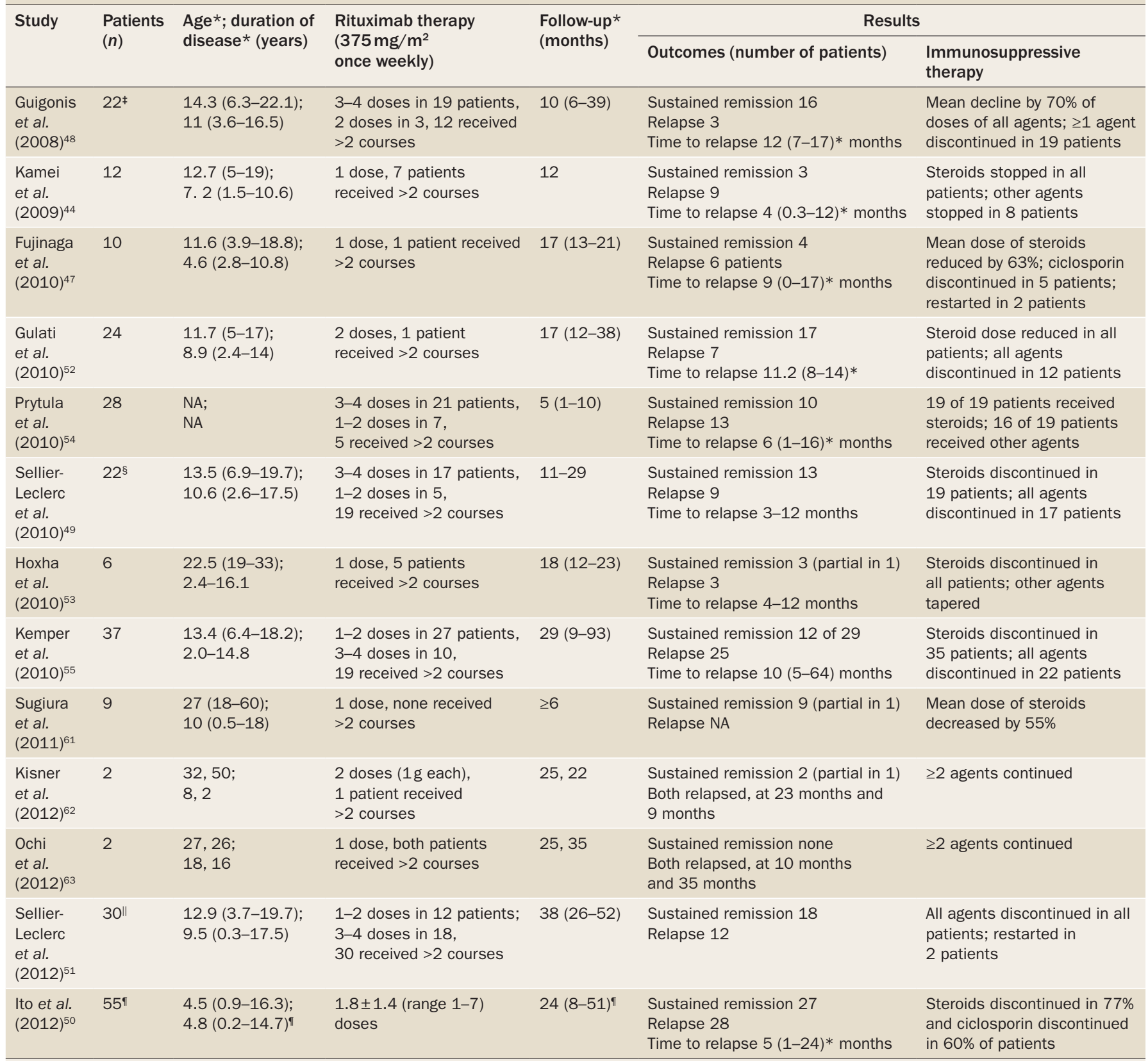

* Median (range). *Includes two patients with steroid-resistant nephrotic syndrome who responded to ciclosporin. \$Includes three patients from another study. ${ }^{8} \|$ IIncludes 18 patients from another study. ${ }^{49}$ IIncludes $\geq 15$ patients from other reports; ${ }^{44,47,67}$ medians (ranges) quoted refer to values reported for the entire series of 74 patients. ${ }^{50}$ Abbreviation: NA, not available.

such as nephrotoxicity, hyperglycaemia, headaches and dyslipidaemia. ${ }^{57-59}$ Therapies that enable steroid sparing without substantially increased adverse effects are, therefore, needed.

Rituximab was first reported to induce remission of nephrotic syndrome in a boy aged 16 years who was treated for co-existing idiopathic thrombocytopenic purpura. ${ }^{60}$ Since then, other studies have shown the efficacy of this agent in patients with difficultto-treat steroid-dependent nephrotic syndrome (Table 1). ${ }^{44,47-55,61-63}$ Patients in these studies received rituximab as 'rescue therapy', several years after the onset of disease; previous therapies included three or more immunosuppressive agents in $30-100 \%$ of patients and calcineurin inhibitors in $42-100 \%$ of patients.

\section{Clinical responses to therapy}

Encouraging results have been reported for patients treated with rituximab for severe steroid-dependent or ciclosporin-dependent nephrotic syndrome. In a prospective, multicentre study, 19 of 22 patients treated with 2-4 doses of rituximab had a satisfactory response with sustained remission and successful withdrawal of one or more immunosuppressive agents. ${ }^{48}$ Four patients (18.2\%) relapsed at 7-17 months. A questionnaire survey conducted by the International Pediatric 


\section{REVIEWS}

Table 2 | The efficacy of rituximab compared to other strategies in difficult-to-treat nephrotic syndrome

\begin{tabular}{|c|c|c|c|c|c|}
\hline Study & $\begin{array}{l}\text { Patients } \\
(n)\end{array}$ & $\begin{array}{l}\text { Study design and } \\
\text { duration of follow-up }\end{array}$ & Study groups & Age (years) & Outcome \\
\hline \multicolumn{6}{|c|}{ Steroid-dependent nephrotic syndrome } \\
\hline $\begin{array}{l}\text { Ravani } \\
\text { et al. } \\
(2011)^{65}\end{array}$ & 54 & $\begin{array}{l}\text { Open-label randomized } \\
\text { controlled trial; } \\
\text { stratified for } \\
\text { prednisolone or } \mathrm{CNI} \\
\text { toxicity; } \geq 3 \text { months }\end{array}$ & $\begin{array}{l}\text { Rituximab } 1-2 \text { doses plus CNI } \\
\text { and tapered prednisolone }(n=27) \\
\text { vs CNI and prednisolone; tapered } \\
\text { if patient in remission }(n=27)\end{array}$ & $\begin{array}{l}10.2 \pm 4.0 \\
\text { vs } 11.3 \pm 4.3\end{array}$ & $\begin{array}{l}\text { Proteinuria } 69.8 \% \text { lower in rituximab group ( } P=0.003) \\
\text { Patients with relapses: } 18.5 \% \text { with rituximab vs } \\
48.1 \% \text { without rituximab }(P=0.029) \\
\text { Probability of successful withdrawal of prednisolone } \\
\text { and } C N I \text { : } 62.9 \% \text { with rituximab vs } 3.7 \% \text { without } \\
\text { rituximab }(P<0.001) \\
\text { Patients who were relapse-free with rituximab: } 50 \% \\
\text { at } 6 \text { months; } 25 \% \text { at } 12 \text { months }\end{array}$ \\
\hline $\begin{array}{l}\text { Ito et al. } \\
(2012)^{67}\end{array}$ & 16 & $\begin{array}{l}\text { Retrospective survey, } \\
1 \text { year }\end{array}$ & $\begin{array}{l}\text { Rituximab } 1 \text { dose plus } 1 \text { year } \\
\text { of mycophenolate mofetil }(n=9) \\
\text { vs rituximab } 1 \text { dose }(n=7) \\
\text { Prednisolone tapered by } \\
2-3 \text { months in both groups }\end{array}$ & $\begin{array}{l}6.8-18.1 \\
\text { vs } 5.0-19.9\end{array}$ & $\begin{array}{l}\text { Relapses: } 3 \text { of } 9 \text { combination-treated patients vs } 6 \\
\text { of } 7 \text { patients }(P<0.05) \\
\text { Relapse rate: } 0.4 \text { vs } 2.3 \text { per year }(P<0.005) \\
\text { Prednisolone dose: } 0.11 \text { vs } 0.29 \mathrm{mg} / \mathrm{kg} \text { daily }(P<0.05) \\
\text { Adverse effects and CD19 depletion in both groups }\end{array}$ \\
\hline \multicolumn{6}{|c|}{ Resistance to steroids and calcineurin inhibitors } \\
\hline $\begin{array}{l}\text { Magnasco } \\
\text { et al. } \\
(2012)^{66}\end{array}$ & 31 & $\begin{array}{l}\text { Open-label randomized } \\
\text { controlled trial; } \\
15 \text { months }\end{array}$ & $\begin{array}{l}\text { Rituximab } 2 \text { doses, } 2 \text { weeks apart, } \\
\text { with prednisolone and tacrolimus or } \\
\text { ciclosporin }(n=16) \text { vs prednisolone } \\
\text { and tacrolimus or ciclosporin }(n=15)\end{array}$ & $\begin{array}{l}8.5 \pm 4.4 \\
\text { vs } 7.3 \pm 3.7\end{array}$ & $\begin{array}{l}\text { No difference in proteinuria at } 3 \text { months }(P=0.77) \\
\text { Similar proportions of patients with initial and } \\
\text { delayed-onset steroid-resistant nephrotic syndrome } \\
\text { responded in both groups }\end{array}$ \\
\hline \multicolumn{6}{|c|}{ FSGS undergoing kidney transplantation } \\
\hline $\begin{array}{l}\text { Fornoni } \\
\text { et al. } \\
(2011)^{35}\end{array}$ & 41 & $\begin{array}{l}\text { Prospective; } \\
\text { retrospective controls; } \\
\geq 1 \text { year }\end{array}$ & $\begin{array}{l}\text { Rituximab } 1 \text { dose, given within } 24 \mathrm{~h} \\
\text { of kidney transplant }(n=27) \text { vs no } \\
\text { rituximab ( } n=14) \\
\text { Induction therapy; triple } \\
\text { immunosuppression in all patients } \\
\text { None received plasma exchange }\end{array}$ & $\begin{array}{l}15.0 \pm 5.5 \\
\text { vs } 12.3 \pm 5.2\end{array}$ & $\begin{array}{l}\text { Patients with recurrent nephrotic syndrome: } 7 \text { vs } 9 \\
(P=0.023) \\
\text { Patients with plasma exchange: } 8 \text { vs } 10(P=0.019) \\
\text { Change in eGFR: }-5.3 \pm 18.4 \text { vs }-19 \pm 19.8 \mathrm{ml} / \\
\text { min/1.73 } \mathrm{m}^{2}(P=0.008) \\
\text { Renal allograft survival similar in both groups at } \\
6 \text { months and } 12 \text { months }\end{array}$ \\
\hline
\end{tabular}

Abbreviations: CNI, calcineurin inhibitor; eGFR, estimated glomerular filtration rate; FSGS, focal segmental glomerulosclerosis.

Nephrology Association (IPNA) provided data on 28 patients given $1-4$ doses of rituximab. ${ }^{54} 23$ patients (82.1\%) had a favourable response, which was sustained in 10 patients for a median of 4.5 months. In a study of 24 patients given two doses of rituximab $\left(375 \mathrm{mg} / \mathrm{m}^{2}\right.$ once a week) at our centre, 20 patients $(83.3 \%)$ were in remission at 1 year and $17(71 \%)$ patients were in remission at 17 months. ${ }^{52}$ These findings were confirmed in a large cohort that included 40 patients, of whom more than two-thirds were in sustained remission at 12 months. ${ }^{64}$ A nationwide survey conducted in Japan showed the efficacy of rituximab in 55 patients with frequently relapsing or steroid-dependent nephrotic syndrome. ${ }^{50}$ After a mean of $1.8 \pm 1.4$ doses of this agent, $49.1 \%$ of patients were in remission at $7-31$ months, and immunosuppressive therapy was discontinued in the majority of patients. ${ }^{50}$

Data on relapse rates are limited. In three studies including a total of 46 children, therapy with rituximab reduced the frequency of relapses by $62-95 \% .^{44,47,52}$ The proportion of patients who achieved sustained remission depended on the dosing strategy and duration of followup (Table 1). In patients who received one dose of rituxi$\mathrm{mab}\left(375 \mathrm{mg} / \mathrm{m}^{2}\right), 25-40 \%$ were in sustained remission at $12-17$ months. ${ }^{44,47}$ Among patients who received
$2-4$ doses of rituximab, $>70 \%$ were in sustained remission at 6-38 months. ${ }^{49,52,55,62}$ Another study reported a significantly longer time to relapse in 11 patients given four doses of rituximab than in 16 patients who received one or two doses $(23.3 \pm 18.7$ months versus $10.3 \pm 3.5$ months, respectively). ${ }^{55}$ However, a correlation between the response to treatment and the number of doses was not seen in the IPNA questionnaire study. ${ }^{54}$

Treatment with rituximab enables considerable steroid sparing, with a substantial reduction in the steroid dose and discontinuation of other immunosuppressive therapies (see Table 1). Since most patients who receive rituximab have long-standing steroid-dependent disease with adverse effects related to therapy, the ability to discontinue steroid therapy is important.

\section{Comparative studies}

Few studies have compared the efficacy and safety of rituximab with that of other immunosuppressive agents (Table 2) ${ }^{65,66}$ The results of a randomized controlled trial in 54 patients with difficult-to-treat, steroid-dependent nephrotic syndrome showed that the combination of rituximab, calcineurin inhibitors and prednisone was not inferior to standard therapy with calcineurin inhibitors and prednisone in maintaining short-term remission. ${ }^{65}$ 
Compared with standard therapy, the additional use of rituximab produced a significant decline in proteinuria, relapse rates and steroid doses. However, the duration of follow-up was short and the implications of these findings for long-term management are unclear.

Another research group compared therapeutic outcomes at 1 year in nine patients who received combination therapy consisting of a single dose of rituximab and oral mycophenolate mofetil, and seven patients given rituximab alone. ${ }^{67}$ The combined therapy resulted in a higher proportion of patients who achieved sustained remission and a longer time to first relapse than did single-dose rituximab. This finding was confirmed in a survey of patients in Japan, which showed relapses in 15 of $40(37.5 \%)$ rituximab-treated patients who continued to receive ciclosporin, mycophenolate mofetil or mizoribine, compared with 13 of 15 (86.7\%) patients treated with rituximab alone, usually in a single dose. ${ }^{50}$ However, another study did not show similar benefit in patients who continued to receive maintenance immunosuppression with ciclosporin after one or more doses of rituximab. ${ }^{55}$ Further studies are necessary to examine whether the number of rituximab doses might determine the need for subsequent therapy with immunosuppressive agents. Our research group has retrospectively compared the outcomes of 23 patients with difficult-to-treat, steroid-dependent nephrotic syndrome who received either rituximab (two or three doses of $375 \mathrm{mg} / \mathrm{m}^{2}$ once a week) or oral tacrolimus (0.1-0.2 $\mathrm{mg} / \mathrm{kg}$ per day for $12 \mathrm{months})$ in combination with prednisolone. ${ }^{68}$ At 12 months, the two treatments had similar efficacy: the reductions in the frequency of relapses, the proportion of patients in sustained remission and decline in the steroid dose received were comparable. ${ }^{68}$ The results from a prospective, multicentre, open-label trial (as yet published only as an abstract), show that therapy with one or two doses of rituximab leads to a significant decline in the relapse rate; 14 of 24 $(58.3 \%)$ patients with steroid-dependent or frequently relapsing nephrotic syndrome achieved remission despite withdrawal of all immunosuppressive medications. ${ }^{69}$

\section{Treatment recommendations}

Treatment with rituximab seems to be a promising approach for patients with difficult-to-treat, steroiddependent nephrotic syndrome, but these positive results require confirmation in prospective studies. A double-blind placebo-controlled trial to evaluate the efficacy and safety of four doses of rituximab in patients with childhood-onset, frequently relapsing, steroiddependent nephrotic syndrome is currently underway. ${ }^{4,70}$ Another trial is underway to examine the efficacy of two doses of rituximab in maintaining remission in patients who are calcineurin-inhibitor dependent. ${ }^{71}$

While awaiting the results of these and future studies (Supplementary Box 1 online), we propose that rituximab should be used as rescue therapy in patients who have failed to respond to multiple immunosuppressive agents or in patients with calcineurin inhibitor toxicity. Treatment with rituximab might also be considered as an alternative to calcineurin inhibitors in patients with severe steroid-dependent nephrotic syndrome. Rituximab should be given during remission, at a dose of $375 \mathrm{mg} / \mathrm{m}^{2}$ once a week for two or more doses, to achieve CD19 levels below 1\% of leukocytes. Although additional therapy with mycophenolate mofetil for up to 12 months might enable patients to achieve sustained remission, the indications for its use need to be defined. Re-treatment with rituximab with or without mycophenolate mofetil is an option in patients who show recurrence of frequent relapses.

\section{Steroid-resistant nephrotic syndrome}

The efficacy of rituximab therapy in patients with difficult-to-treat, steroid-resistant nephrotic syndrome was first investigated in five patients (three of whom had FSGS) who received four doses of rituximab, administered once weekly. ${ }^{72}$ Four patients achieved complete remission and one had partial remission. Subsequently, other studies have shown success with rituximab treatment in a proportion of patients with minimal change disease or FSGS refractory to treatment with steroids and calcineurin inhibitors. ${ }^{73-75}$ Table 3 summarizes the current experience with rituximab in patients with steroid-resistant nephrotic syndrome..$^{50,52,54,61-63,76-79}$ All patients in these studies had nephrotic syndrome of long-standing duration and had received prior therapy with two or more agents, including corticosteroids, cyclophosphamide or calcineurin inhibitors.

\section{Response to therapy}

The four largest case series that evaluated the efficacy of rituximab included a total of 87 patients (11 of whom were adults, Table 3). ${ }^{50,52,54,77}$ The participants comprised almost equal proportions of patients with minimal change disease and FSGS. ${ }^{50,52,54,77}$ The indication for treatment was immediate or delayed unresponsiveness to calcineurin inhibitors, with or without overt toxic effects. Complete remission was seen in $0-27.3 \%$ of patients and partial remission in $21.2-37.5 \%$ of patients, for an overall remission rate of $45.6 \%$ patients. ${ }^{50,52,54,77}$ The timing of remission was variable, usually occurring within 4-6 weeks from completion of therapy, and was sustained for 6-24 months. In the patients who achieved remission, treatment with immunosuppressive agents could be tapered or discontinued. ${ }^{50,52,54,77}$

One study reported complete or partial remission of proteinuria in 10 of 11 adults treated with rituximab; however, information on the efficacy of therapy was not provided separately for patients with steroiddependent nephrotic syndrome or steroid-resistant nephrotic syndrome. ${ }^{79}$ Other reports indicate satisfactory remission rates with rituximab therapy in patients with steroid-resistant nephrotic syndrome, although their small sample sizes, limited follow-up periods and the confounding effects of concomitant therapies make it difficult to define the efficacy of this intervention. A randomized controlled trial to evaluate the efficacy and safety of rituximab has been carried out in 31 children (aged 2-16 years) with nephrotic syndrome who had 


\section{REVIEWS}

Table 3 Studies on the efficacy of rituximab in steroid-resistant nephrotic syndrome

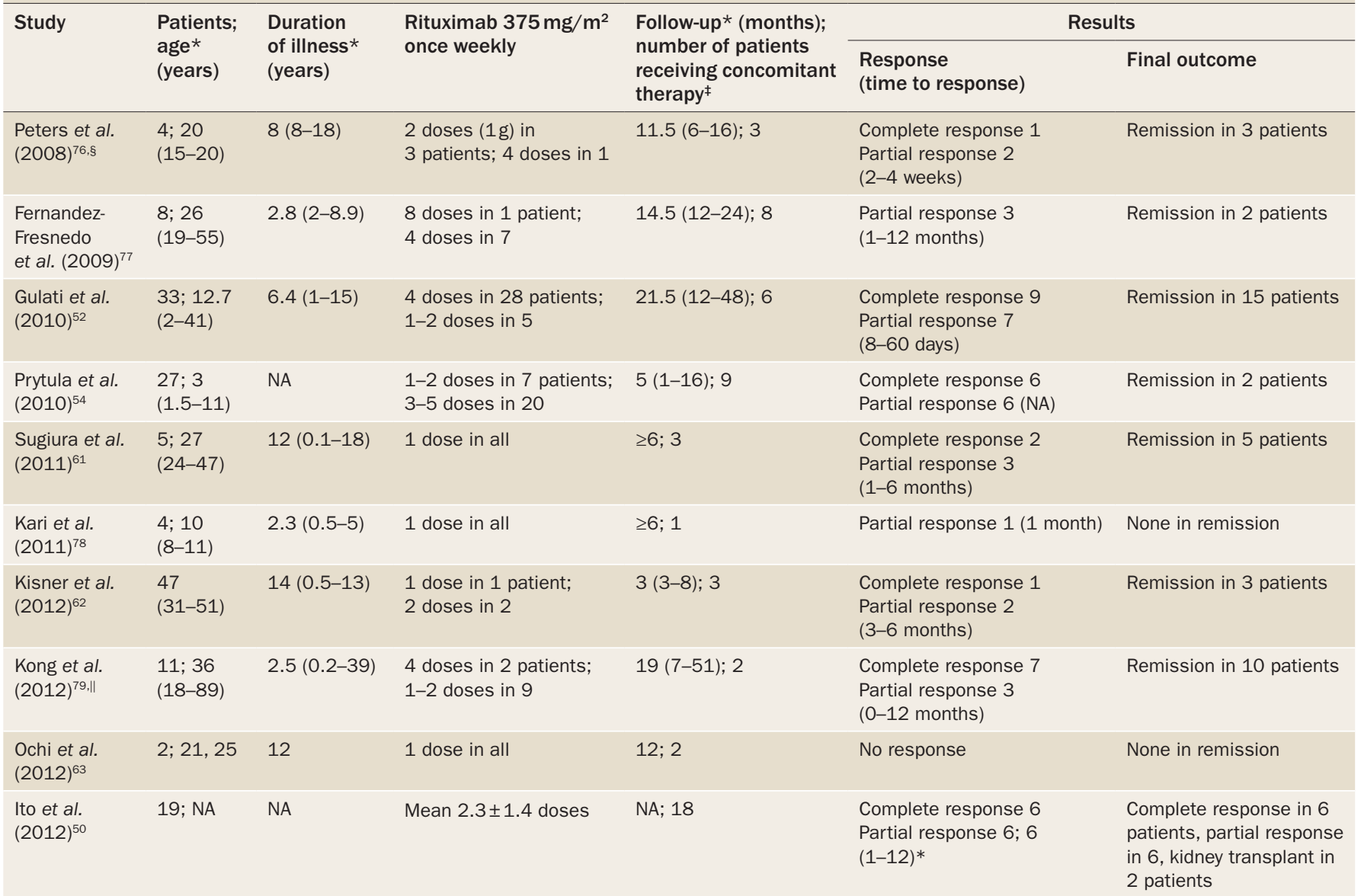

*Median (range). ${ }^{\ddagger}$ Concomitant therapy with mycophenolate mofetil and calcineurin inhibitors; all patients received an angiotensin-converting-enzyme inhibitor or angiotensin-receptor blocker and corticosteroids. \$Includes one patient with recurrent focal segmental glomerulosclerosis, who responded to four doses of rituximab with partial remission at 7 months. IIncludes 7 patients with steroid-dependent nephrotic syndrome (six with minimal change disease, one with focal segmental glomerulosclerosis); information on decline in relapse rates not reported. Abbreviation: NA, not available.

not responded to treatment with calcineurin inhibitors and prednisone. ${ }^{66}$ All patients continued their existing medications, and one group was randomly assigned to receive additional therapy consisting of two doses of rituximab. Although depletion of B cells and adequate serum levels of rituximab were achieved, this therapy did not induce remission or reduce proteinuria in these patients (Table 2).

\section{Factors affecting response to therapy}

Steroid-resistant nephrotic syndrome is a heterogeneous disease and the response of patients to immunosuppressive agents is influenced by multiple factors, including the presence of minimal change disease or FSGS, duration of illness and previous therapies. Approximately $20-35 \%$ of patients respond to treatment with alkylating agents, and 60-70\% respond to treatment with calcineurin inhibitors. Rituximab therapy has been used chiefly in patients who do not respond to the above agents. However, the published studies have not identified any clinical or biochemical predictors of response to rituximab, or any relationship between the number of doses and the response to this treatment. ${ }^{54,77}$ Furthermore, many patients in these studies continued to receive one or more immunosuppressive agents, including calcineurin inhibitors, which might confound the effect of therapy with rituximab. ${ }^{61,63,77}$

Our experience suggests that findings on renal histology can help to predict the response of patients to treatment with rituximab: remission occurred in $64.7 \%$ of patients with minimal change disease, compared to $31.3 \%$ of patients with FSGS. ${ }^{52}$ Collation of data from other case series suggests that patients with minimal change disease are significantly more likely to respond to treatment than those with FSGS (Figure 2)..$^{50,54,61-63,76-79}$

\section{Treatment recommendations}

Almost $60-70 \%$ of patients with steroid-resistant nephrotic syndrome treated with calcineurin inhibitors achieve complete or partial remission, ${ }^{9}$ and at present no alternative agent shows superior efficacy. However, therapy with rituximab might be useful in two instances. First, in patients who respond to calcineurin inhibitors, treatment with 2-4 doses of rituximab might be used to maintain remission and enable withdrawal of calcineurin inhibitors, especially in the presence of drug-related toxic effects. Second, the results of retrospective case series suggest that treatment with rituximab might be effective 
in some patients with nephrotic syndrome resistant to corticosteroid and calcineurin inhibitor therapy. However, the results of a randomized controlled trial that examined the efficacy of rituximab in such patients were not encouraging. ${ }^{66}$ Adequately powered studies with long-term follow-up of groups of patients stratified for renal histology are required to clarify the benefits of these treatment strategies.

\section{Recurrent FSGS}

Patients with idiopathic FSGS and persistent proteinuria in the nephrotic range are at risk of developing kidney failure that requires renal transplantation. Approximately $30 \%$ of such patients develop recurrence of FSGS after the first allograft. ${ }^{80,81}$ Features associated with FSGS recurrence include onset of nephrotic syndrome below the age of 15 years, rapid progression to end-stage renal disease (within 3 years from onset), mesangial proliferation on renal histopathology, white ethnicity and nongenetic (immune) forms of FSGS. ${ }^{82,83}$ The increased risk of FSGS recurrence in children who receive renal grafts from living donors ${ }^{84}$ is balanced by the reduced risk of rejection and decreased need for immunosuppression. ${ }^{85}$ Recurrence of FSGS usually occurs within hours to days after the transplant procedure, and is characterized by proteinuria in the nephrotic range and progressive hypoalbuminaemia. ${ }^{6}$ These patients are at increased risk of allograft failure (5-year kidney graft survival is $57 \%$ in patients with recurrent FSGS versus $82 \%$ in patients without recurrence) ${ }^{86,87}$ After the loss of the first allograft, the risk of recurrence of FSGS in subsequent kidney transplants is $80-100 \% .{ }^{88}$

Strategies for the management of patients with recurrent FSGS include the use of plasma exchange or immunoadsorption in combination with high-dose ciclosporin and cyclophosphamide. By using these strategies, $70 \%$ of children and $63 \%$ of adults with recurrent FSGS achieve complete or partial remission. ${ }^{89}$ In one case report, a decline in proteinuria was observed after rituximab therapy in a boy aged 12 years with recurrent FSGS treated for post-transplant lymphoproliferative disorder. ${ }^{90}$ Subsequently, some researchers have reported remission of proteinuria with the use of rituximab (2-6 doses of $375 \mathrm{mg} / \mathrm{m}^{2}$, administered once every 1-2 weeks) in conjunction with plasma exchange and post-transplantation immunosuppression.

Experience with rituximab therapy in patients with recurrent FSGS has been summarized in a systematic review ${ }^{6}$ and a multicentre report (Table 4$) .{ }^{54}$ The review included data on 39 patients with recurrent FSGS. Proteinuria in the nephrotic range and hypoalbuminaemia were present in $74.3 \%$ of patients within 1 month of kidney transplantation. ${ }^{6}$ Combined therapy with plasmapheresis and rituximab resulted in complete or partial remission of proteinuria in $64.1 \%$ of patients. The median time to best clinical response was 2 months (range 0.6-12.0 months). On univariate analysis, a young age at transplantation, normal serum albumin level at recurrence of FSGS and the need for fewer rituximab infusions was associated with an improved response

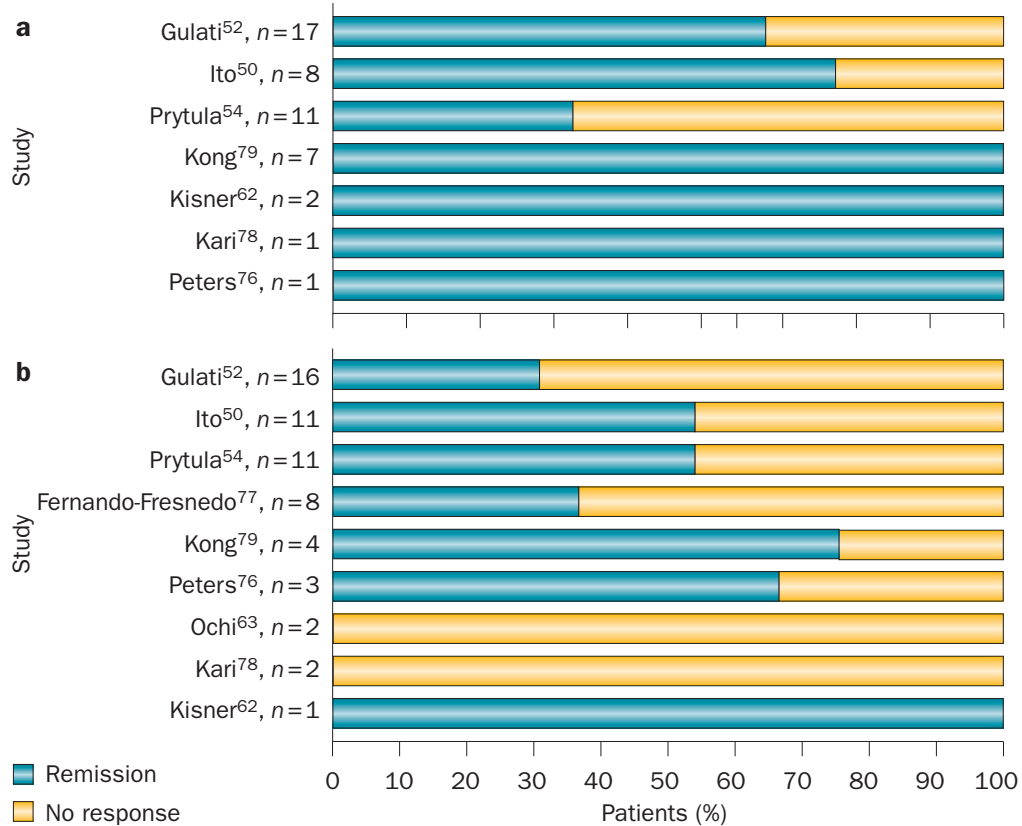

Figure 2 | Rates of remission after rituximab therapy. Data obtained from studies in patients with $\mathbf{a} \mid$ minimal change disease and $\mathbf{b} \mid$ focal segmental glomerulosclerosis. Remission was observed in 32 of 47 patients (68.1\%) with minimal change disease, and 26 of 58 patients (44.8\%) with focal segmental glomerulosclerosis $(P=0.017)$.

to treatment. Response was not related to the kidney donor type (living or deceased), the use of pretransplant or post-transplant plasmapheresis, other immunosuppressive therapy or the post-transplant severity of proteinuria. On stepwise regression analysis, normal serum albumin level at recurrence (which implies mild FSGS) and young age predicted a favourable response to rituximab therapy. ${ }^{6}$ The IPNA study showed that therapy with 1-4 doses of rituximab in combination with plasmapheresis resulted in complete or partial remission in nine of $15(60 \%)$ patients (Table 4$){ }^{54}$ Five of the seven patients treated with B-cell depletion showed complete or partial remission; two patients (one with and one without B-cell depletion) were nonresponders. ${ }^{54}$ In a review of data from 25 patients with recurrent FSGS treated with rituximab infusions and plasma exchange, the 12 patients who achieved remission had received rituximab infusions significantly earlier than the 13 patients who did not respond (mean 100.5 \pm 95.4 days from the onset of recurrence versus $468.1 \pm 379.8$ days, respectively).$^{91}$

In another report, six of eight patients with recurrent FSGS refractory to plasmapheresis achieved complete or partial remission with 1-4 doses of rituximab. ${ }^{92}$ Furthermore, patients who had relapses of proteinuria responded to re-treatment with rituximab. Treatment with plasmapheresis and two doses of rituximab induced complete or partial remission in four adults with recurrent FSGS (Table 4). ${ }^{93}$ Other reports indicate similar findings that rituximab is effective in sustaining remission in patients who either do not respond to or who are dependent on plasmapheresis. ${ }^{94-96}$ Although the possibility that these patients had a delayed response 


\section{REVIEWS}

Table 4 | Efficacy of rituximab in treatment and prevention* of recurrent FSGS

\begin{tabular}{|c|c|c|c|c|c|}
\hline Characteristics & $\begin{array}{l}\text { Tsagalis et al. } \\
(2010)^{93}\end{array}$ & Araya et al. $(2011)^{6}$ & Prytula et al. (2009) $)^{54}$ & $\begin{array}{l}\text { Audard et al. } \\
(2012)^{98 *}\end{array}$ & Kumar et al. (2012) ${ }^{92}$ \\
\hline Patients $(n)$ & 4 & 39 & 15 & 4 & 8 \\
\hline Age (range) & $32-57$ years & $\begin{array}{l}\text { 5-48 years; } 19 \text { children } \\
\text { (age not specified) }\end{array}$ & $\begin{array}{l}\text { All children } \\
\text { (age not specified) }\end{array}$ & 28-43 years & 5-17 years \\
\hline Time to recurrence (range) & 2-72 months & $1-3,513$ days & NA & No recurrence & $\begin{array}{l}\text { Immediate in } 7 \\
\text { patients; at } 4 \text { years in } 1\end{array}$ \\
\hline $\begin{array}{l}\text { Post-transplant plasma } \\
\text { exchange (patients); number } \\
\text { of sessions or duration }\end{array}$ & 4; 20-69 sessions & 38; mean 21 sessions & 10; NA & $\begin{array}{l}2 ; 6 \text { and } 15 \\
\text { sesssions }\end{array}$ & $\begin{array}{l}\text { All; } 3 \text { days to } \\
61 \text { months }\end{array}$ \\
\hline $\begin{array}{l}\text { Rituximab regimen } \\
\text { ( } 375 \mathrm{mg} / \mathrm{m}^{2} \text { infusion, } \\
\text { unless specified) }\end{array}$ & $\begin{array}{l}1 \mathrm{~g} ; 2 \text { doses every } \\
2 \text { weeks, repeated at } \\
1 \text { year }\end{array}$ & $1-6$ doses & $\begin{array}{l}1-4 \text { doses every } \\
1-2 \text { weeks }\end{array}$ & $\begin{array}{l}1-2 \text { doses on } \\
\text { day } 0(n=4) \text { and } \\
\text { day } 7(n=2)\end{array}$ & $\begin{array}{l}1-10 \text { doses (including } \\
\text { repeat courses) }\end{array}$ \\
\hline Duration of follow-up & $18-60$ months & NA & 5-84 months & $12-54$ months & 1-41 months \\
\hline Outcome at last follow-up & $\begin{array}{l}\text { Complete remission } 2 \\
\text { Partial remission } 2\end{array}$ & $\begin{array}{l}\text { Complete remission } 17 \\
\text { Partial remission } 8\end{array}$ & $\begin{array}{l}\text { Complete or partial } \\
\text { remission } 5 \\
\text { Recurrence } 3 \\
\text { NA } 1\end{array}$ & No recurrence & $\begin{array}{l}\text { Complete or partial } \\
\text { remission } 5 \\
1 \text { death }\end{array}$ \\
\hline
\end{tabular}

to plasmapheresis cannot be excluded, the timing of response correlated with that of rituximab therapy.

\section{Prevention of recurrent FSGS}

Combined therapy with rituximab and pretransplant plasmapheresis is useful in kidney transplant recipients at high risk of recurrence of FSGS. Therapy with 1-2 doses of rituximab and multiple sessions of plasmapheresis prevented recurrent FSGS in recipients of a second kidney transplant who were followed up for 12-54 months. ${ }^{97}$ In a report, a girl aged 7.9 years with a history of recurrent FSGS was successfully managed using four sessions of plasmapheresis and a single dose of rituximab $\left(375 \mathrm{mg} / \mathrm{m}^{2}\right) 21$ days before transplantation. ${ }^{98}$ In another report, administration of rituximab within $24 \mathrm{~h}$ after transplantation prevented recurrence of FSGS (Table 2).$^{35}$ Recurrent FSGS was noted in $25.9 \%$ of 27 patients treated with rituximab, compared with $64.3 \%$ of 14 patients who did not receive the medication. ${ }^{35}$ However, the overall incidence of FSGS recurrence in this study was considerably higher than that reported in the literature; the recurrence rate in patients receiving rituximab was close to that cited elsewhere for untreated patients.

\section{Treatment recommendations}

All patients with FSGS who are about to undergo renal transplantation should be advised about the possibility of recurrence of this disease. Pre-emptive plasma exchange should be planned in advance of living-donor transplantation. ${ }^{99}$ Early and aggressive therapy with immunosuppression and plasma exchange should be initiated if proteinuria develops after transplantation.

The efficacy of rituximab in patients with recurrent FSGS is difficult to estimate owing to confounding effects from other concomitant therapies. Combination therapy with plasma exchange and rituximab has shown promise in the prevention and treatment of recurrent FSGS, but the efficacy of this approach needs to be examined in prospective controlled studies. ${ }^{82}$ Rituximab is cleared from the body by plasma exchange; ${ }^{100}$ we suggest, therefore, an interval of $36-48 \mathrm{~h}$ between rituximab infusion and plasmapheresis.

\section{Idiopathic membranous glomerulonephritis}

Membranous nephropathy is the principal cause of nephrotic syndrome in adults, ${ }^{101,102}$ among whom idiopathic membranous nephropathy accounts for $32-80 \%$ of diagnoses. Secondary causes of membranous nephropathy include systemic lupus erythematosus, chronic infections (especially hepatitis B), medications or malignancy. ${ }^{103,104}$ Spontaneous remission occurs in $30-40 \%$ of patients within $12-24$ months. ${ }^{105}$ Current therapies include inhibitors of the renin-angiotensinaldosterone system, and combinations of corticosteroids with alkylating agents or calcineurin inhibitors. ${ }^{106}$ The results of randomized trials indicate that therapy with the above-mentioned agents can induce remission in $59-90 \%$ of patients; however, relapse rates are high and patients with proteinuria in the nephrotic range can develop progressive renal failure. ${ }^{107,108}$ The efficacy of rituximab was initially reported in eight patients with 
Table 5 | Efficacy of rituximab in patients with idiopathic membranous glomerulonephritis

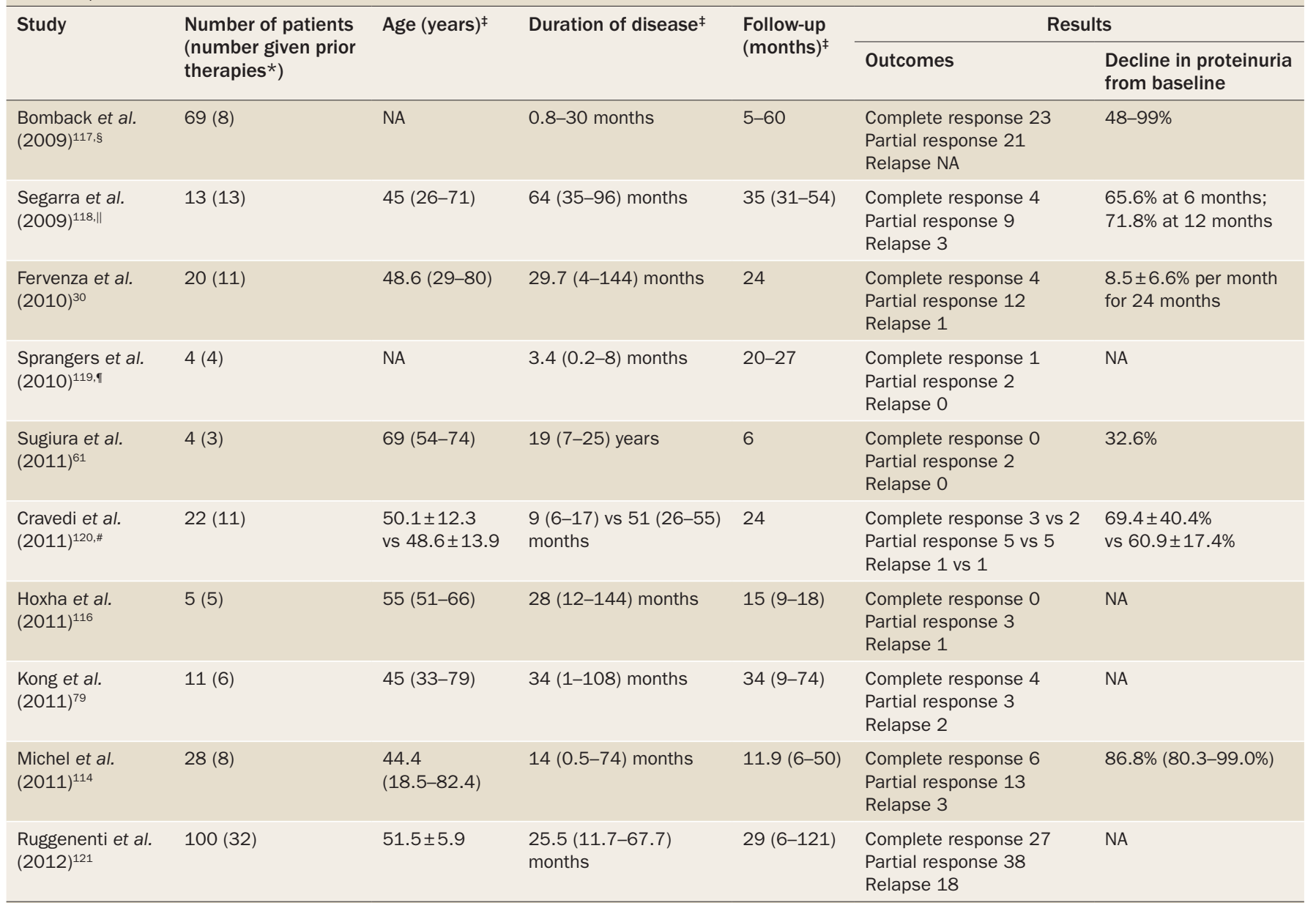

*Alkylating agents, mycophenolate mofetil or calcineurin inhibitors; almost all patients were treated with angiotensin-converting-enzyme inhibitors and/or angiotensin-receptor blockers. ${ }^{\ddagger}$ Median (range). \$Includes two patients with disease recurrence after transplantation. IIncludes patients with calcineurin-inhibitor-dependent nephrotic syndrome and partial remission who had not relapsed in the past 2 months. Includes patients with disease recurrence after transplantation. "11 patients who received rituximab as first-line therapy were compared with 11 patients who failed to respond to prior immunosuppressive therapies. Abbreviation: NA, not available.

membranous nephropathy, ${ }^{109}$ but this agent has since been used in the treatment of both idiopathic and secondary forms of the disease, as first-line therapy and after patients fail to respond to standard therapy.

\section{Pathogenesis of membranous glomerulonephritis}

Membranous glomerulonephritis is thought to result from an immune response in which podocyte antigens are targeted by circulating IgG4 antibodies. Subepithelial deposition of these immune complexes results in podocyte injury and loss of the filtration barrier. Of particular interest is an autoantibody against the M-type isoform of the phospholipase $\mathrm{A} 2$ receptor (PLA2R). ${ }^{110}$ Support for a pathogenetic role of this autoantibody comes from findings of associations between titres of this antibody and nephrotic range proteinuria or post-transplant recurrence of idiopathic membranous nephropathy. ${ }^{111-113}$ Positive staining for PLA2R was found in immune deposits in kidney biopsy samples from patients with membranous nephropathy. ${ }^{114}$ Patients with membranous nephropathy and autoantibodies against PLA2R often also have elevated levels of antibodies against other antigens, including neutral endopeptidase, aldose reductase, superoxide dismutase 2 and $\alpha$-enolase. ${ }^{115}$ Although rituximab therapy does not remove circulating autoantibodies, treated patients show a decline in the titre of anti-PLA2R antibodies and remission of proteinuria. ${ }^{45,111,114,116}$ Table 5 and Supplementary Figure 1 online show the clinical response of patients with membranous nephropathy to rituximab. ${ }^{30,61,114,116-121}$ However, heterogeneity in previous therapies, dosing schedules of rituximab and definitions of response (Box 1) make it difficult to collate data from these studies.

The efficacy of rituximab therapy has been assessed in a systematic review of data from 21 studies, including 69 patients with idiopathic membranous nephropathy. ${ }^{117}$ The complete response rate was $15-20 \%$ and the partial response rate was $35-40 \%$. Although these figures are inferior to those reported for treatment with alkylating agents and calcineurin inhibitors, many patients in these studies had previously failed to respond to the above therapies. ${ }^{117}$ In a prospective cohort study of 100 consecutive patients with membranous nephropathy who were followed up for 2.5 years after treatment with 1-4 doses of rituximab, complete and partial remission occurred in 27 and 38 patients, respectively, at a median 
of 7.1 months (range 3.2-12.0 months). ${ }^{121}$ One-third of patients in this cohort had failed to respond to previous therapy with other medications. Remission was seen in 47 of $68(69.1 \%)$ patients given rituximab as the primary immunosuppressive agent, and in 18 of 32 (56.3\%) patients who received rituximab after the failure of an alternative immunosuppressive agent. Remission rates were similar in a prospective cohort of patients treated with rituximab as first-line therapy and a retrospective cohort of patients who received this agent as secondline therapy and were matched for age, sex and severity of proteinuria. ${ }^{120}$ Three separate reports provide information on the efficacy of rituximab in the treatment of patients with post-transplantation recurrence of membranous nephropathy. ${ }^{117,119,122}$ Therapy with $1-8$ doses of rituximab stabilized renal function and induced complete or partial remission in 13 of 14 patients, ${ }^{117,119,122}$ including those who required re-treatment. ${ }^{122}$

A prospective study indicates that the proportion of patients with membranous nephropathy who achieve complete and partial remission increases over time, indicating a delayed response. ${ }^{121}$ Other studies have also reported increasing rates of remission during extended follow-up up $^{3014,120}$ and that remission is sustained after B-cell recovery. These observations might reflect gradual clearance of glomerular immune deposits, correction of pathological abnormalities and/or resolution of proteinuria. Although these patients might relapse, re-treatment with rituximab is effective in inducing further remission. ${ }^{14,116,118-121}$ Most studies do not provide information on the effect of rituximab therapy on kidney function; however, in one study, the glomerular filtration rate (GFR) increased in patients with complete remission, but progressively declined in those who did not respond to therapy. ${ }^{121}$ Other studies confirm that remission of membranous nephropathy improves ${ }^{30,118}$ or stabilizes ${ }^{114,119,120}$ renal function.

Predictors of a lack of response to rituximab therapy in patients with membranous nephropathy include a high tubulointerstitial score, tubular atrophy and interstitial fibrosis in kidney biopsy samples, ${ }^{123}$ and impaired renal function at baseline (estimated GFR $<45 \mathrm{ml}$ / $\left.\mathrm{min} / 1.73 \mathrm{~m}^{2}\right) .{ }^{114}$ By contrast, in another case series, no relationship was noted between the response to therapy and histological findings. ${ }^{30}$ In one study, urinary excretion of a 1 microglobulin, retinol-binding protein, albumin and $\operatorname{IgG}$ at baseline correlated well with the rate of response to rituximab at 12 months but not at 24 months. $^{124}$

Reports demonstrate that anti-PLA2R antibody titres decline after therapy with rituximab. Antibodies to PLA2R were detected at baseline in 10 of 28 patients treated with rituximab, and were absent in all five patients tested for these antibodies after complete or partial remission. ${ }^{114}$ In a case series, a decline in antiPLA2R antibody titre was associated with a reduction in proteinuria in two patients, whereas the three patients in whom anti-PLA2R antibody titres increased did not enter remission. ${ }^{115}$ These findings were confirmed in another study, which showed that patients with decreasing anti-PLA2R antibody levels after rituximab treatment had increased rates of remission at 12 and 24 months. ${ }^{108}$

\section{Treatment recommendations}

The 2012 Kidney Disease: Improving Global Outcomes guidelines recommend that immunosuppressive therapy should be initiated in patients with idiopathic membranous nephropathy who have nephrotic syndrome, proteinuria of $\geq 4$ g per day and estimated GFR $\geq 30 \mathrm{ml} /$ $\mathrm{min} / 1.73 \mathrm{~m}^{2}$ who fail to respond to 6 months of treatment with antihypertensive and antiproteinuric agents. ${ }^{107}$ An initial immunosuppressive regimen that combines corticosteroids and an alkylating agent is recommended, if that fails calcineurin inhibitors should be used. Therapy with 2-4 doses of rituximab is likely to result in complete remission in $20-33 \%$ of patients and partial remission in $20-60 \%$ of patients who fail to respond to treatment with cyclophosphamide or calcineurin inhibitors. ${ }^{7}$ The results of ongoing prospective studies are expected to clarify the benefits of this medication. ${ }^{125,126}$

\section{Adverse effects of rituximab}

Therapy with rituximab is well tolerated in most patients; however, a number of adverse affects have been documented (Table 6). ${ }^{4,52,55,62,76,77,127}$

\section{Infusion reactions}

Acute reactions can occur within the first 30-120 min of an infusion, ${ }^{5,117}$ with an incidence that ranges from $9.1 \%$ to $56.3 \% .^{30,47,48,50,51,54,67,79,114,121}$ Commonly reported reactions include flu-like symptoms, chills, fever, headache, myalgia, itching, erythematous rash, ${ }^{30,44,47,48,54,55,66,68,117,120,121}$ cough, sore throat, nasal congestion, tachycardia, ${ }^{44,48}$ and hypotension ${ }^{44,48,121}$ or hypertension. ${ }^{44,76}$ These symptoms can be minimized by pretreatment with antihistamines and/or corticosteroids. The intensity of symptoms declines on stopping the infusion and they rarely recur. Anaphylaxis ${ }^{54,128}$ and/or bronchospasm ${ }^{44,48,65,66,117,121}$ are rarely reported in association with rituximab infusions. In view of the risk of infusion reactions, cautious administration is advised, beginning with a slow infusion rate and increasing the rate at $30 \mathrm{~min}$ intervals. In adult oncology practice, the first dose of rituximab is infused over $6 \mathrm{~h}$ and subsequent doses are given over a 4 h period. $^{129}$

\section{Risk of infections}

Patients receiving rituximab are at increased risk of infections with usual or unusual organisms, including pyogenic infections, tuberculosis and cytomegalovirus. ${ }^{51,117,130}$ The risk of infections is also increased by concomitant use of other immunosuppressive agents and the underlying disorder. Since CD20 is not present on plasma cells, immunoglobulin production is not altered and the risk of hypogammaglobulinaemia is low (Table 6). ${ }^{44,47,48,54,61,118,131,132}$ However, low serum levels of immunoglobulins have been noted in a few patients receiving maintenance rituximab after haematopoietic stem cell transplantation, ${ }^{133}$ malignancies ${ }^{134}$ 
or autoimmune cytopenias. ${ }^{135}$ A meta-analysis of data from three placebo-controlled randomized trials (including 938 patients) of rituximab therapy in patients with rheumatoid arthritis showed no increase in the incidence of infections. ${ }^{136}$ Systematic reviews of rituximab therapy in patients with lymphomas show that this treatment is associated with a twofold increase in the risk of neutropenia and infections ${ }^{137-139}$ compared with standard therapy, perhaps as a result of the increased dosage of rituximab and the underlying disease The dose specified is higher than usually used for nephrotic syndrome. Patients with nephrotic syndrome treated with rituximab may show transient leukopenia associated with bacterial sepsis or pneumonia caused by Pneumocystis jiroveci (formerly known as $P$. carinii), ${ }^{48,51,52,54,76,140}$ similar to that reported in patients with haematologic malignancies or rheumatoid arthritis. ${ }^{141}$ Therefore, the use of cotrimoxazole prophylaxis should be considered in patients with nephrotic syndrome who are receiving rituximab therapy and concomitant immunosuppression. A report on 19 patients with difficult-to-treat systemic lupus erythematosus who were given two doses of rituximab showed exacerbation of herpes zoster infection in five patients. ${ }^{142}$ Another study reported increased infection-related mortality in 77 kidney transplant recipients treated with rituximab. ${ }^{143}$ By contrast, infection rates were similar in 170 highly sensitized kidney transplant recipients treated with rituximab and intravenous immunoglobulin and in 191 nonsensitized patients who did not receive this combination therapy. ${ }^{144}$

Patients with non-Hodgkin lymphoma and collagen vascular disorders treated with rituximab are at risk of reactivation of hepatitis $B$ infection, resulting in fulminant liver failure. ${ }^{145}$ The use of rituximab should, therefore, be avoided in patients who are positive for hepatitis B antigens. ${ }^{146}$

\section{Progressive multifocal leukoencephalopathy}

Evidence indicates a possible association between longterm rituximab therapy and progressive multifocal leukoencephalopathy (PML), an encephalitis caused by JC polyomavirus. ${ }^{147}$ Multiple case reports describe PML in rituximab-treated patients with haematological malignancies, systemic lupus erythematosus and rheumatoid arthritis, which have prompted modification of current prescribing information (including a 'black box' warning). ${ }^{148}$ Patients with PML show a gradual onset of cognitive impairment, motor weakness, speech problems and deterioration of vision. The diagnosis is made on the basis of these clinical features, MRI findings and demonstration of polyomavirus in brain biopsy samples or cerebrospinal fluid.

PML has not been reported in patients with nephrotic syndrome treated with rituximab. Screening of blood and urine specimens from 11 children with nephrotic syndrome treated with rituximab and eight controls showed the presence of JC virus in the urine of one patient and one control. ${ }^{149} \mathrm{BK}$ virus was found in the urine of seven patients and two controls, and in blood samples from four patients. ${ }^{149}$ The above findings suggest the need
Table 6 | Rituximab-associated adverse effects

\begin{tabular}{|c|c|c|}
\hline Adverse effect & Patients (\% of total) & Reference(s) \\
\hline Infusion-related reactions & 140 of $624(22.4)$ & $\begin{array}{l}30,44,47,48,50-52,54,55,64-67 \\
76,79,114,117,120,121,126\end{array}$ \\
\hline Acute reactions & 84 of $379(22.2)$ & $\begin{array}{l}30,47,48,50,51,54,67,79 \\
114,121\end{array}$ \\
\hline Anaphylaxis & 4 of $77(5.2)$ & 54,128 \\
\hline $\begin{array}{l}\text { Rash, flushing } \\
\text { or itching }\end{array}$ & 27 of $511(5.3)$ & $\begin{array}{l}30,44,47,48,50,54,55,64,66,117 \\
120,121\end{array}$ \\
\hline $\begin{array}{l}\text { Bronchospasm } \\
\text { or dyspnoea }\end{array}$ & 30 of $321(9.4)$ & $44,48,50,65,66,117,121$ \\
\hline Hypotension & 4 of $193(2.1)$ & $44,48,50,121$ \\
\hline Hypertension & 2 of $75(2.7)$ & $44,50,76$ \\
\hline $\begin{array}{l}\text { Abdominal pain } \\
\text { and vomiting }\end{array}$ & 7 of $97(7.2)$ & $48,50,66$ \\
\hline Chills & 9 of $152(5.9)$ & $52,64,117$ \\
\hline Myalgia & 3 of $152(2.0)$ & $52,64,117$ \\
\hline Tachycardia or arrhythmia & 4 of $93(4.3)$ & $44,48,50$ \\
\hline $\begin{array}{l}\text { Arthritis or serum } \\
\text { sickness }\end{array}$ & 3 of $112(2.7)$ & 65,117 \\
\hline \multicolumn{3}{|l|}{ Infections } \\
\hline Septicaemia & 3 of $214(1.4)$ & $50,54,117$ \\
\hline Pneumonia & 7 of $222(3.2)$ & $30,48,54,79,117,140$ \\
\hline Diarrhoea & 2 of 52 (3.9) & 48,51 \\
\hline Fever of infectious origin & 3 of $89(3.4)$ & 50,51 \\
\hline $\begin{array}{l}\text { Human herpesvirus } 6 \\
\text { infection }\end{array}$ & 1 of $30(3.3)$ & 51 \\
\hline $\begin{array}{l}\text { Catheter-related sepsis, } \\
\text { BK-virus-associated } \\
\text { nephropathy }\end{array}$ & 1 of 2 & 130 \\
\hline $\begin{array}{l}\text { Herpes zoster } \\
\text { reactivation }\end{array}$ & 1 of $85(1.2)$ & 117 \\
\hline \multicolumn{3}{|l|}{ Laboratory tests } \\
\hline Neutropenia* & 10 of $248(4.0)$ & $48,50-52,54,76,93$ \\
\hline Thrombocytopenia & 1 of $30(3.3)$ & 51 \\
\hline $\begin{array}{l}\text { Elevation of } \\
\text { transaminases }\end{array}$ & 1 of $89(1.1)$ & 50,51 \\
\hline Hypogammaglobulinaemia & 5 of $156(3.2)$ & $44,47,48,54,61,72,118$ \\
\hline \multicolumn{3}{|l|}{ Anecdotal reports ${ }^{\ddagger}$} \\
\hline $\begin{array}{l}\text { Acute lung injury or } \\
\text { interstitial pneumonitis }\end{array}$ & 4 & $55,92,152,153$ \\
\hline Colitis or pancolitis & 2 & 44,127 \\
\hline Cardiomyopathy & 1 & 44 \\
\hline Acute kidney injury & 2 & 44,92 \\
\hline CNS glioma & 1 & 92 \\
\hline
\end{tabular}

*Associated with infections in two patients. ₹Precise number not available. Abbreviation: CNS, central nervous system.

for increased awareness regarding these infections in immunocompromised patients.

\section{Rituximab-associated lung injury}

Rituximab can cause delayed pulmonary toxicity, chiefly in adults treated for B-cell lymphoma ${ }^{150}$ and other disorders. ${ }^{151}$ Two systematic reviews on rituximab-induced 
lung disease (in $121^{151}$ and $30^{152}$ patients, respectively) suggest a mortality rate of 14.9-29.0\%. Pulmonary symptoms usually occur after a mean of four (range 1-12) doses of rituximab, 1-3 months after the last infusion. Clinical features include dyspnoea, fever, nonproductive cough and hypoxaemia, with bilateral lung infiltrates, reduced diffusion capacity and a restrictive ventilatory pattern. Rarely, patients have hypoxaemia and respiratory insufficiency after the first infusion. ${ }^{153}$ Pathological findings include bronchiolitis obliterans organizing pneumonia, interstitial pneumonitis, acute respiratory distress syndrome and hypersensitivity pneumonitis. ${ }^{154}$ Acute lung injury with thrombotic microangiopathy, multiorgan dysfunction and death was reported in one patient treated with rituximab for recurrent FSGS. ${ }^{92}$

Rituximab should be used cautiously in patients with underlying lung disease, and a diagnosis of rituximabrelated lung injury should be considered in any patient who develops respiratory symptoms or new radiographic changes after therapy. Affected patients are treated with supportive care and corticosteroids, although the efficacy of steroids is not proven. ${ }^{152}$

\section{Human antichimaeric antibodies}

Repeated use of rituximab in patients with systemic lupus erythematosus and lymphoma is associated with the formation of human antichimaeric antibodies. ${ }^{155,156}$ The presence of host antibodies to the murine peptide sequences in rituximab might cause an anaphylactic reaction in some patients or, by increasing rituximab clearance, reduce its efficacy. ${ }^{73,157,158}$ The presence of human antichimaeric antibodies in six of 14 patients with idiopathic membranous nephropathy did not affect the response to rituximab. ${ }^{30}$ Development of human antichimaeric antibodies is thought to be linked to the rituximab dosing schedule, since they are more common in patients who received one rather than four doses of this agent. ${ }^{2,158,159}$ The development of human antichimaeric antibodies might be minimized with the use of new humanized or fully human monoclonal antibodies against CD20. ${ }^{160}$

\section{Conclusions}

Rituximab has mild to moderate efficacy and a favourable safety profile in patients with difficult-to-treat nephrotic syndrome. However, the current literature on its efficacy in this setting is based chiefly on case series and data from very few randomized controlled trials. For this reason, firm recommendations cannot yet be presented for its use in clinical practice. Despite the limitations of the available evidence, satisfactory results have been obtained with rituximab therapy in patients with refractory steroid-dependent nephrotic syndrome, recurrent FSGS and membranous nephropathy. By contrast, this treatment has limited benefits in patients with steroid-resistant nephrotic syndrome. Prospective, randomized controlled studies with adequate sample sizes and appropriate follow-up are necessary to define the indications for therapy with rituximab therapy, and to determine outcomes and predictors of response.

Review criteria
We searched PubMed and EMBASE for full-text articles
mainly in the English language published from January
2002 to October 2012, using the following terms:
"nephrotic syndrome", "rituximab", "CD20", "minimal
change", "focal segmental glomerulosclerosis",
"recurrent FSGS", "membranous glomerulonephritis"
and "membranous nephropathy". The reference lists of
selected publications were reviewed to identify additional
relevant articles. To reduce publication bias, we included
data from systematic reviews and studies including four
or more patients, except in the case of papers relating
to recurrent focal segmental glomerulosclerosis and
adverse effects, for which even single case reports were
considered. Studies by the same group of authors were
scrutinized to avoid overlap in the reporting of findings
derived from the same patients.

1. Amoroso, A. et al. Understanding rituximab function and resistance: implications for tailored therapy. Front. Biosci. 16, 770-782 (2011).

2. Ejaz, A. A., Asmar, A., Alsabbagh, M. M. \& Ahsan, N. Rituximab in immunologic glomerular diseases. mAbs 4, 198-207 (2012).

3. US Food and Drug Administration. News and events [online], http://www.fda.gov/ NewsEvents/Newsroom/PressAnnouncements/ ucm251946.htm (2012).

4. lijima, K. Rituximab for childhood refractory nephrotic syndrome. Pediatr. Int. 53, 617-621 (2011).

5. Takei, T. \& Nitta, K. Rituximab and minimal change nephrotic syndrome: a therapeutic option. Clin. Exp. Nephrol. 15, 641-647 (2011).

6. Araya, C. E. \& Dharnidharka, V. R. The factors that may predict response to rituximab therapy in recurrent focal segmental glomerulosclerosis: a systematic review. J. Transplant. http:// dx.doi.org/10.1155/2011/374213.

7. Appel, G. B. Rituximab in membranous nephropathy: is it a first-line treatment? J. Am. Soc. Nephrol. 23, 1280-1282 (2012).
8. Kidney Disease Improving Global Outcomes (KDIGO). General principles in the management of glomerular disease. Kidney Int. Suppl. 2, 156-162 (2012).

9. Gulati, A. et al. Treatment with tacrolimus and prednisolone is preferable to intravenous cyclophosphamide as the initial therapy for children with steroid-resistant nephrotic syndrome. Kidney Int. 82, 1130-1135 (2012).

10. Troyanov, S. et al. Idiopathic membranous nephropathy: definition and relevance of a partial remission. Kidney Int. 66, 1199-1205 (2004).

11. Cragg, M. S., Walshe, C. A., Ivanov, A. O. \& Glennie, M. J. The biology of CD20 and its potential as a target for mAb therapy. Curr. Dir. Autoimmun. 8, 140-174 (2005).

12. Hofmeister, J. K., Cooney, D. \& Coggeshall, K. M. Clustered CD20 induced apoptosis: src-family kinase, the proximal regulator of tyrosine phosphorylation, calcium influx and caspase 3-dependent apoptosis. Blood Cells Mol. Dis. 26, 133-143 (2000).

13. Cartron, G., Watier, H., Golay, J. \& Solal-Celigny, P. From the bench to the bedside: ways to improve rituximab efficacy. Blood 104, 2635-2642 (2004).

14. Semac, I. et al. Anti-CD20 therapeutic antibody rituximab modifies the functional organization of rafts/microdomains of $\mathrm{B}$ lymphoma cells. Cancer Res. 63, 534-540 (2003).

15. Koyama, A., Fujisaki, M., Kobayashi, M., Igarashi, M. \& Narita, M. A glomerular permeability factor produced by human $\mathrm{T}$ cell hybridomas. Kidney Int. 40, 453-460 (1991).

16. Vallerskog, T. et al. Treatment with rituximab affects both the cellular and the humoral arm of the immune system in patients with, S.L.E. Clin. Immunol. 122, 62-74 (2007).

17. Stasi, R. et al. Analysis of regulatory T-cell changes in patients with idiopathic thrombocytopenic purpura receiving B celldepleting therapy with rituximab. Blood 112, 1147-1150 (2008).

18. Vigna-Perez, M. et al. Clinical and immunological effects of rituximab in patients with lupus nephritis refractory to conventional therapy: a pilot study. Arthritis Res. Ther. 8, R83 (2006).

19. Sfikakis, P. P. et al. Increased expression of the FoxP3 functional marker of regulatory $T$ cells 
following B cell depletion with rituximab in patients with lupus nephritis. Clin. Immunol. 123, 66-73 (2007).

20. Saadoun, D. et al. Restoration of peripheral immune homeostasis after rituximab in mixed cryoglobulinemia vasculitis. Blood 111, 5334-5341 (2008).

21. Sfikakis, P. P. et al. Remission of proliferative lupus nephritis following B cell depletion therapy is preceded by down-regulation of the T cell costimulatory molecule CD40 ligand. Arthritis Rheum. 52, 501-513 (2005).

22. Tokunaga, M. et al. Down-regulation of CD40 and CD80 on B cells in patients with life-threatening systemic lupus erythematosus after successful treatment with rituximab. Rheumatology (Oxford) 44, 176-182 (2005).

23. Hu, C. Y. et al. Treatment with CD20-specific antibody prevents and reverses autoimmune diabetes in mice. J. Clin. Invest. 117, 3857-3867 (2007).

24. Araya, C. et al. T regulatory cell function in idiopathic minimal lesion nephrotic syndrome. Pediatr. Nephrol. 24, 1691-1698 (2009).

25. Le Berre, L. et al. Induction of T regulatory cells attenuates idiopathic nephrotic syndrome. J. Am. Soc. Nephrol. 20, 57-67 (2009).

26. Shao, X. S. et al. The prevalence of $\mathrm{T}_{\mathrm{H}} 17$ cells and FOXP3 regulate T cells (Treg) in children with primary nephrotic syndrome. Pediatr. Nephrol. 24, 1683-1690 (2009).

27. Wang, L., Li, Q., Wang, L. J. \& Li, X. Level of $T_{H} 17$ cell and $\mathrm{CD}^{+}$; $\mathrm{CD}_{25} 5^{+}$; Foxp $3^{+}$; regulatory T cells in peripheral blood mononuclear cells of primary nephrotic syndrome in children [Chinese]. Xi Bao Yu Fen Zi Mian Yi Xue Za Zhi 26, 783-786 (2010).

28. Bertelli, R. et al. Failure of regulation results in an amplified oxidation burst by neutrophils in children with primary nephrotic syndrome. Clin. Exp. Immunol. 161, 151-158 (2010).

29. Shimada, M. et al. Minimal change disease: a "two-hit" podocyte immune disorder? Pediatr. Nephrol. 26, 645-649 (2011).

30. Fervenza, F. C. et al. Rituximab therapy in idiopathic membranous nephropathy: a 2-year study. Clin. J. Am. Soc. Nephrol. 5, 2188-2198 (2010).

31. Yeo, W. S. et al. Effect of rituximab on T-cell subsets in nephrotic children with focal segmental glomerulosclerosis (FSGS) [abstract F-P01277]. J. Am. Soc. Nephrol. 21, 403 (2010).

32. Lin, C. Y. Immune modulatory mechanism of rituximab in steroid refractory heavy proteinuria [abstract SA-P0377]. J. Am. Soc. Nephrol. 23, 724 (2012).

33. Perosa, F., Favoino, E., Caragnano, M. A. \& Dammacco, F. Generation of biologically active linear and cyclic peptides has revealed a unique fine specificity of rituximab and its possible cross-reactivity with acid sphingomyelinase-like phosphodiesterase $3 \mathrm{~b}$ precursor. Blood 107, 1070-1077 (2006).

34. Bezombes, C. et al. Rituximab antiproliferative effect in B lymphoma cells is associated with acid-sphingomyelinase activation in raft microdomains. Blood 104, 1166-1173 (2004).

35. Fornoni, A. et al. Rituximab targets podocytes in recurrent focal segmental glomerulosclerosis. Sci. Transl. Med. 3, 85-95 (2011).

36. Tan, R. et al. Nef interaction with actin compromises human podocyte actin cytoskeletal integrity. Exp. Mol. Pathol. 94, 51-57 (2013).

37. Wei, C. et al. Circulating urokinase receptor as a cause of focal segmental glomerulosclerosis. Nat. Med. 17, 952-960 (2011).

38. Chan, C. Y., Yeo, W. S., Wei, C., Biswas, S. K. \& Yap, H. K. High suPAR levels in FSGS patients is associated with decreased $T_{\text {REG }}$ cells [abstract FR-P0483]. J. Am. Soc. Nephrol. 23, 484 (2012).

39. US National Library of Medicine. ClinicalTrials.gov [online], http://clinicaltrials.gov/ct2/show/ NCT01573533 (2012).

40. Liu, L. L. et al. $T_{H} 17 / T_{R E G}$ imbalance in adult patients with minimal change nephrotic syndrome. Clin. Immunol. 139, 314-320 (2011).

41. Ng, C. M., Bruno, R., Combs, D. \& Davies, B. Population pharmacokinetics of rituximab (anti-CD20 monoclonal antibody) in rheumatoid arthritis patients during a phase II clinical trial. J. Clin. Pharmacol. 45, 792-801 (2005).

42. Breedveld, F. et al. Rituximab pharmacokinetics in patients with rheumatoid arthritis: B-cell levels do not correlate with clinical response. J. Clin. Pharmacol. 47, 1119-1128 (2007).

43. Berinstein, N. L. et al. Association of serum rituximab (IDEC-C2B8) concentration and antitumor response in the treatment of recurrent low-grade or follicular non-Hodgkin's lymphoma. Ann. Oncol. 9, 995-1001 (1998).

44. Kamei, K. et al. Single dose of rituximab for refractory steroid-dependent nephrotic syndrome in children. Pediatr. Nephrol. 24, 1321-1328 (2009).

45. Fervenza, F. C. et al. Rituximab treatment of idiopathic membranous nephropathy. Kidney Int. 73, 117-125 (2008).

46. Regazzi, M. B. et al. Pharmacokinetic behavior of rituximab: a study of different schedules of administration for heterogenous clinical settings. Ther. Drug Monit. 27, 785-792 (2005).

47. Fujinaga, S. et al. Single infusion of rituximab for persistent steroid-dependent minimal-change nephrotic syndrome after long-term cyclosporine. Pediatr. Nephrol. 25, 539-544 (2010).

48. Guigonis, V. et al. Rituximab treatment for severe steroid- or cyclosporine-dependent nephrotic syndrome: a multicentric series of 22 cases. Pediatr. Nephrol. 23, 1269-1279 (2008).

49. Sellier-Leclerc, A. L. et al. Rituximab efficiency in children with steroid-dependent nephrotic syndrome. Pediatr. Nephrol. 25, 1109-1115 (2010).

50. Ito, S. et al. Survey of rituximab treatment for childhood-onset refractory nephrotic syndrome. Pediatr. Nephrol. http://dx.doi.org/10.1007/ s00467-012-2319-1.

51. Sellier-Leclerc, A. L. et al. Rituximab in steroid dependent idiopathic nephrotic syndrome in childhood: follow-up after CD19 recovery. Nephrol. Dial. Transplant. 27, 1083-1089 (2012).

52. Gulati, A. et al. Efficacy and safety of treatment with rituximab for difficult steroid-resistant and -dependent nephrotic syndrome: multicentric report. Clin. J. Am. Soc. Nephrol. 5, 2207-2212 (2010).

53. Hoxha, E., Stahl, R. A. \& Harendza, S. Rituximab in adult patients with immunosuppressivedependent minimal change disease. Clin. Nephrol. 76, 151-158 (2011).

54. Prytula, A. et al. Rituximab in refractory nephrotic syndrome. Pediatr. Nephrol. 25, 461-468 (2010).

55. Kemper, M. J. et al. Long-term follow-up after rituximab for steroid-dependent idiopathic nephrotic syndrome. Nephrol. Dial. Transplant. 27, 1910-1915 (2012).

56. Bagga, A. \& Mantan, M. Nephrotic syndrome in children. Indian J. Med. Res. 122, 13-28 (2005).

57. Kidney Disease Improving Global Outcomes (KDIGO). Steroid-sensitive nephrotic syndrome in children. Kidney Int. Suppl. 2, 163-171 (2012).

58. Hodson, E. M., Willis, N. S. \& Craig, J. C. Noncorticosteroid treatment for nephrotic syndrome in children. Cochrane Database of Systematic
Reviews, Issue 1. Art. No.: CD002290. http:// dx.doi.org/10.1002/14651858.CD002290. pub3.

59. Ishikura, K. et al. Effective and safe treatment with cyclosporine in nephrotic children: a prospective, randomized multicenter trial. Kidney Int. 73, 1167-1173 (2008).

60. Benz, K., Dötsch, J., Rascher, W. \& Stachel, D. Change of the course of steroid-dependent nephrotic syndrome after rituximab therapy. Pediatr. Nephrol. 19, 794-797 (2004).

61. Sugiura, H. et al. Effect of single-dose rituximab on primary glomerular diseases. Nephron Clin. Pract. 117, c98-c105 (2011).

62. Kisner, T., Burst, V., Teschner, S., Benzing, T. \& Kurschat, C. E. Rituximab treatment for adults with refractory nephrotic syndrome: a singlecenter experience and review of the literature. Nephron Clin. Pract. 120, c79-c85 (2012).

63. Ochi, A. et al. Rituximab treatment for adult patients with focal segmental glomerulosclerosis. Intern. Med. 51, 759-762 (2012).

64. Sinha, A., Bhatia, D., Gulati, A., Hari, P. \& Bagga, A. Efficacy and safety of rituximab in difficult steroid resistant \& dependent nephrotic syndrome [abstract OP64]. Pediatr. Nephrol. 27, 1605-1829 (2012).

65. Ravani, P. et al. Short-term effects of rituximab in children with steroid- and calcineurin-dependent nephrotic syndrome: a randomized controlled trial. Clin. J. Am. Soc. Nephrol. 6, 1308-1315 (2011).

66. Magnasco, A. et al. Rituximab in children with resistant idiopathic nephrotic syndrome. J. Am. Soc. Nephrol. 23, 1117-1124 (2012).

67. Ito, S. et al. Maintenance therapy with mycophenolate mofetil after rituximab in pediatric patients with steroid-dependent nephrotic syndrome. Pediatr. Nephrol. 26, 1823-1828 (2011).

68. Sinha, A., Bagga, A., Gulati, A. \& Hari, P. Shortterm efficacy of rituximab versus tacrolimus in steroid-dependent nephrotic syndrome. Pediatr. Nephrol. 27, 235-241 (2012).

69. Ruggenenti, P. et al. Rituximab in steroiddependent or multirelapsing nephrotic syndrome of adults and children: results from the NEMO trial [abstract SA-P0375]. J. Am. Soc. Nephrol. 23, 484 (2012).

70. Japan Medical Association for Clinical Trials. Double-Blind Study of IDEC-C2B8 in patients with childhood-onset refractory nephrotic syndrome. JMACCT Clinical Trials Registry [online], https://dbcentre3.jmacct.med.or.jp/ imactr/App/JMACTRE02_04/JMACTRE02_04. aspx? $k b n=3 \&$ seqno $=662$ (2012).

71. US National Library of Medicine. ClinicalTrials.gov [online], http://clinicaltrials.gov/show/ NCT01268033 (2012).

72. Bagga, A., Sinha, A. \& Moudgil, A. Rituximab in patients with the steroid-resistant nephrotic syndrome. N. Engl. J. Med. 356, 2751-2752 (2007).

73. Kurosu, N. et al. Successful use of single-dose rituximab for the maintenance of remission in a patient with steroid-resistant nephrotic syndrome. Intern. Med. 48, 1901-1904 (2009).

74. Suri, M., Tran, K., Sharma, A. P., Filler, G. \& Grimmer, J. Remission of steroid-resistant nephrotic syndrome due to focal and segmental glomerulosclerosis using rituximab. Int. Urol. Nephrol. 40, 807-810 (2008).

75. Nakayama, M. et al. Rituximab for refractory focal segmental glomerulosclerosis. Pediatr. Nephrol. 23, 481-485 (2008).

76. Peters, H. P., van de Kar, N. C. \& Wetzels, J. F. Rituximab in minimal change nephropathy and 
focal segmental glomerulosclerosis: report of four cases and review of the literature. Neth. J. Med. 66, 408-415 (2008).

77. Fernandez-Fresnedo, G. et al. Rituximab treatment of adult patients with steroid-resistant focal segmental glomerulosclerosis. Clin. J. Am. Soc. Nephrol. 4, 1317-1323 (2009).

78. Kari, J. A. et al. Rituximab for refractory cases of childhood nephrotic syndrome. Pediatr. Nephrol. 26, 733-737 (2011)

79. Kong, W. Y., Swaminathan, R. \& Irish, A. Our experience with rituximab therapy for adult-onset primary glomerulonephritis and review of literature. Int. Urol. Nephrol. http://dx.doi.org/ 10.1007/s11255-012-0206-0.

80. Couser, W. Recurrent glomerulonephritis in the renal allograft: an update of selected areas. Exp. Clin. Transplant. 3, 283-288 (2005).

81. Ponticelli, C. \& Glassock, R. J. Posttransplant recurrence of primary glomerulonephritis. Clin. J. Am. Soc. Nephrol. 5, 2363-2372 (2010).

82. Vinai, M., Waber, P. \& Seikaly, M. G. Recurrence of focal segmental glomerulosclerosis in renal allograft: an in-depth review. Pediatr. Transplant. 14, 314-325 (2010).

83. Weber, S. et al. NPHS2 mutation analysis shows genetic heterogeneity of steroid-resistant nephrotic syndrome and low post-transplant recurrence. Kidney Int. 66, 571-579 (2004).

84. Baum, M. A. et al. Loss of living donor renal allograft survival advantage in children with focal segmental glomerulosclerosis. Kidney Int. 59, 328-333 (2001).

85. Cibrik, D. M., Kaplan, B., Campbell, D. A. \& Meier-Kriesche, H. U. Renal allograft survival in transplant recipients with focal segmental glomerulosclerosis. Am. J. Transplant. 3, 64-67 (2003).

86. Hariharan, S. et al. Recurrent and de novo glomerular disease after renal transplantation: a report from Renal Allograft Disease Registry (RADR). Transplantation 68, 635-641 (1999).

87. Pardon, A. et al. Risk factors and outcome of focal and segmental glomerulosclerosis recurrence in adult renal transplant recipients. Nephrol. Dial. Transplant. 21, 1053-1059 (2006).

88. Newstead, C. G. Recurrent disease in renal transplants. Nephrol. Dial. Transplant. 18 (Suppl. 6), 68-74 (2003).

89. Ponticelli, C. Recurrence of focal segmental glomerular sclerosis after renal transplantation. Nephrol. Dial. Transplant. 25, 25-31 (2010).

90. Nozu, K. et al. Rituximab treatment for posttransplant lymphoproliferative disorder induces complete remission of recurrent nephrotic syndrome. Pediatr. Nephrol. 20, 1660-1663 (2005).

91. Sakai, K. et al. Protocol biopsies for focal segmental glomerulosclerosis treated with plasma exchange and rituximab in a renal transplant patient. Clin. Transplant. 24, 60-65 (2010).

92. Kumar, J. et al. Rituximab in post-transplant pediatric recurrent focal segmental glomerulosclerosis. Pediatr. Nephrol. http:// dx.doi.org/10.1007/s00467-012-2314-6.

93. Tsagalis, G., Psimenou, E., Nakopoulou, L. \& Laggouranis, A. Combination treatment with plasmapheresis and rituximab for recurrent focal segmental glomerulosclerosis after renal transplantation. Artif. Organs 35, 420-425 (2011).

94. Stewart, Z. A., Shetty, R., Nair, R., Reed, A. I. \& Brophy, P. D. Case report: successful treatment of recurrent focal segmental glomerulosclerosis with a novel rituximab regimen. Transplant. Proc. 43, 3994-3996 (2011).
95. Gossmann, J. et al. Abrogation of nephrotic proteinuria by rituximab treatment in a renal transplant patient with relapsed focal segmental glomerulosclerosis. Transpl. Int. 20, 558-562 (2007).

96. Grenda, R., Jarmużek, W., Piątosa, B. \& Rubik, J. Long-term effect of rituximab in maintaining remission of recurrent and plasmapheresis-dependent nephrotic syndrome post-renal transplantation-case report. Pediatr. Transplant. 15, e121-e125 (2011).

97. Audard, V. et al. Rituximab therapy prevents focal and segmental glomerulosclerosis recurrence after a second renal transplantation. Transpl. Int. 25, e62-e66 (2012).

98. Chikamoto, H. et al. Pretransplantation combined therapy with plasmapheresis and rituximab in a second living-related kidney transplant pediatric recipient with a very hig risk for focal segmental glomerulosclerosis recurrence. Pediatr. Transplant. 16, e286-e290 (2012).

99. Gohh, R. Y. et al. Preemptive plasmapheresis and recurrence of FSGS in high-risk renal transplant recipients. Am. J. Transplant. 5, 2907-2912 (2005).

100. McDonald, V., Manns, K., Mackie, I. J., Machin, S. J. \& Scully, M. A. Rituximab pharmacokinetics during the management of acute idiopathic thrombotic thrombocytopenic purpura. J. Thromb. Haemost. 8, 1201-1208 (2010).

101. Glassock, R. J. Diagnosis and natural course of membranous nephropathy. Semin. Nephrol. 3, 324-332 (2003).

102. [No authors listed]. Nephrotic syndrome in children: prediction of histopathology from clinical and laboratory characteristics at time of diagnosis. A report of the International Study of Kidney Disease in Children. Kidney Int. 13, 159-165 (1978).

103. Beck, L. H. \& Salant, D. J. Membranous nephropathy: recent travels and new roads ahead. Kidney Int. 77, 765-770 (2010).

104.Zeng, C. H. et al. Etiology and clinical characteristics of membranous nephropathy in Chinese patients. Am. J. Kidney Dis. 52, 691-698 (2008).

105. Polanco, N. et al. Spontaneous remission of nephrotic syndrome in idiopathic membranous nephropathy. J. Am. Soc. Nephrol. 21, 697-704 (2010).

106. Schieppati, A. et al. Immunosuppressive treatment for idiopathic membranous nephropathy in adults with nephrotic syndrome. Cochrane Database of Systematic Reviews, Issue 4. Art. No.: CD004293. http:// dx.doi.org/ search/site/CD004293.

107. Kidney Disease Improving Global Outcomes (KDIGO). Idiopathic membranous nephropathy. Kidney Int. Suppl. 2, 186-197 (2012).

108. Cattran, D. C., Reich, H. N., Kim, S. J. \& Troyanov, S. Have we changed the outcome in membranous nephropathy? A propensity study on the role of immunosuppressive therapy. Clin. J. Am. Soc. Nephrol. 6, 1591-1598 (2011).

109. Remuzzi, G. et al. Rituximab for idiopathic membranous nephropathy. Lancet $\mathbf{3 6 0}$, 923-924 (2002).

110. Beck, L. H. et al. M-type phospholipase A2 receptor as target antigen in idiopathic membranous nephropathy. N. Engl. J. Med. 361, 11-21 (2009).

111. Beck, L. H. Jr et al. Rituximab-induced depletion of anti-PLA2R autoantibodies predicts response in membranous nephropathy. J. Am. Soc. Nephrol. 22, 1543-1550 (2011).
112. Hofstra, J. M., Beck, L. H. Jr, Beck, D. M., Wetzels, J. F. \& Salant, D. J. Antiphospholipase A2 receptor antibodies correlate with clinical status in idiopathic membranous nephropathy. Clin. J. Am. Soc. Nephrol. 6, 1286-1291 (2011).

113. Stahl, R. A. K., Hoxha, E. \& Fechner, K. PLA2R autoantibodies and recurrent membranous nephropathy after transplantation. N. Engl. J. Med. 363, 496-498 (2010).

114. Michel, P. A. et al. Rituximab treatment for membranous nephropathy: a French clinical and serological retrospective study of 28 patients. Nephron Extra 1, 251-261 (2011).

115. Murtas, C. et al. Co-existence of different circulating anti-podocyte antibodies in membranous nephropathy. Clin. J. Am. Soc. Nephrol. http://dx.doi.org/10.2215/ CJN.02170312.

116. Hoxha, E. et al. An immunofluorescence test for phospholipase-A2-receptor antibodies and its clinical usefulness in patients with membranous glomerulonephritis. Nephrol. Dial. Transplant. 26, 2526-2532 (2011).

117. Bomback, A. S. et al. Rituximab therapy for membranous nephropathy: a systematic review. Clin. J. Am. Soc. Nephrol. 4, 734-744 (2009).

118. Segarra, A. et al. Successful treatment of membranous glomerulonephritis with rituximab in calcineurin inhibitor-dependent patients. Clin J. Am. Soc. Nephrol. 4, 1083-1088 (2009).

119. Sprangers, B. et al. Beneficial effect of rituximab in the treatment of recurrent idiopathic membranous nephropathy after kidney transplantation. Clin. J. Am. Soc. Nephrol. 5, 790-797 (2010).

120. Cravedi, P. et al. Efficacy and safety of rituximab second-line therapy for membranous nephropathy: a prospective, matched-cohort study. Am. J. Nephrol. 33, 461-468 (2011).

121. Ruggenenti, P. et al. Rituximab in idiopathic membranous glomerulonephritis, J. Am. Soc. Nephrol. 23, 1416-1425 (2012).

122. Rodriguez, E. F. et al. The pathology and clinical features of early recurrent membranous glomerulonephritis. Am. J. Transplant. 12 1029-1038 (2012).

123. Ruggenenti, P. et al. Rituximab for idiopathic membranous nephropathy: who can benefit? Clin. J. Am. Soc. Nephrol. 1, 738-748 (2006).

124. Irazabal, M. V. et al. Low- and high-molecular-weight urinary proteins as predictors of response to rituximab in patients with membranous nephropathy: a prospective study. Nephrol. Dial. Transplant. http:// dx.doi.org/10.1093/ndt/gfs379.

125. US National Library of Medicine. ClinicalTrials. gov [online], http://clinicaltrials.gov/ct2/ show/NCT01180036 (2012).

126. US National Library of Medicine. ClinicalTrials. gov [online], http://www.clinicaltrials.gov/ct2/ show/NCT01508468?term $=$ NCT01508468\& $r$ ank=1 (2012).

127. Ardelean, D. S. et al. Severe ulcerative colitis after rituximab therapy. Pediatrics 126 , e243-e246 (2010).

128. Strologo, D. L. et al. Use of rituximab in focal glomerulosclerosis relapses after renal transplantation. Transplantation 88, 417-420 (2009).

129. Atmar, J. Review of the safety and feasibility of rapid infusion of rituximab. J. Oncol. Practice 6, 91-93 (2010).

130. Kamar, N. et al. Treatment of focal segmental glomerular sclerosis with rituximab: 2 case reports. Clin. Nephrol. 67, 250-254 (2007).

131. Bayrakci, U. S., Baskin, E., Sakalli, H., Karakayali, H. \& Haberal, M. Rituximab for post- 
transplant recurrences of FSGS. Pediatr. Transplant. 13, 240-243 (2009).

132. Thevenin, C., Lucas, B. P., Kozlow, E. J. \& Kehrl, J. H. Cell type- and stage-specific expression of the CD20/B1 antigen correlates with the activity of a diverged octamer DNA motif present in its promoter. J. Biol. Chem. 268 , 5949-5956 (1993).

133. Lim, S. H. et al. B-cell depletion for 2 years after autologous stem cell transplant for NHL induces prolonged hypogammaglobulinemia beyond the rituximab maintenance period. Leuk. Lymphoma 49, 152-153 (2008)

134. Wang, Q. S. et al. Change of serum immunoglobulin level in patients with diffuse large B cell lymphoma after rituximab combined with chemotherapy [Chinese]. Zhongguo Shi Yan Xue Ye Za Zhi 19, 676-679 (2011).

135. Cooper, N., Davies, E. G. \& Thrasher, A. J. Repeated course of rituximab for autoimmune cytopenias may precipitate profound hypogammaglobulinaemia requiring replacement intravenous immunoglobulin. Br. J. Haematol. 146, 120-122 (2009).

136. Lee, Y. H., Bae, S. C. \& Song, G. G. The efficacy and safety of rituximab for the treatment of active rheumatoid arthritis: a systematic review and meta-analysis of randomized controlled trials. Rheumatol. Int. 31, 1493-1499 (2011).

137. Lanini, S. et al. Risk of infection in patients with lymphoma receiving rituximab: systematic review and meta-analysis. BMC Med. 9, 36 (2011).

138. Vidal, L. et al. Rituximab maintenance for the treatment of patients with follicular lymphoma: an updated systematic review and meta-analysis of randomized trials. J. Natl Cancer Inst. 103, 1799-1806 (2011).

139. Aksoy, S., Dizdar, O., Hayran, M. \& Harputluoğlu, H. Infectious complications of rituximab in patients with lymphoma during maintenance therapy: a systematic review and meta-analysis. Leuk. Lymphoma 50, 357-365 (2009).

140. Sato, M. et al. Atypical Pneumocystis jiroveci pneumonia with multiple nodular granulomas after rituximab for refractory nephrotic syndrome. Pediatr. Nephrol. 1, 145-149 (2013).

141. Teichmann, L. L. et al. Fatal Pneumocystis pneumonia following rituximab administration for rheumatoid arthritis. Rheumatology (Oxford) 47 , 1256-1257 (2008).

142. Podolskaya, A., Stadermann, M., Pilkington, C. Marks, S. D. \& Tullus, K. B cell depletion therapy for 19 patients with refractory systemic lupus erythematosus. Arch. Dis. Child. 93, 401-406 (2008).

143. Kahwaji, J. et al. Infectious complications in kidney-transplant recipients desensitized with rituximab and intravenous immunoglobulin. Clin. J. Am. Soc. Nephrol. 6, 2894-2900 (2011).

144. Kamar, N. et al. Incidence and predictive factors for infectious disease after rituximab therapy in kidney-transplant patients. Am. J. Transplant. 10 89-98 (2010).

145. Tsutsumi, Y. et al. Rituximab administration and reactivation of, H. B. V. Hepat. Res. Treat. http://dx.doi.org/10.1155/2010/182067.

146. Mastroianni, C. M. et al. Current trends in management of hepatitis $B$ virus reactivation in the biologic therapy era. World J. Gastroenterol. 17, 3881-3887 (2011)

147. Bennett, C. L. Pharmacovigilance and PML in the oncology setting. Clin. J. Med. 78 (Suppl. 2), S13-S17 (2011).

148. US Food and Drug Administration. MedWatch: The FDA Safety Information and Adverse Event Reporting Program. Rituxan (rituximab)-PML [online], http://www.fda.gov/Safety/ MedWatch/Safetylnformation/ SafetyAlertsforHumanMedicalProducts/ ucm187791 (2012).

149. Delbue, S. et al. Investigation of polyomaviruses replication in pediatric patients with nephropathy receiving rituximab. J. Med. Virol. 84, 1464-1470 (2012).

150. Herishanu, Y. et al. Fatal interstitial pneumonitis related to rituximab-containing regimen. Clin. Lymphoma Myeloma 6, 407-409 (2006).

151. Hadjinicolaou, A. V., Nisar, M. K., Parfrey, H., Chilvers, E. R. \& Ostor, A. J. Non-infectious pulmonary toxicity of rituximab: a systematic review. Rheumatology (Oxford) 51, 653-662 (2012).

152. Bitzan, M., Anselmo, M. \& Carpineta, L. Rituximab (B-cell depleting antibody) associated lung injury (RALI): pediatric case and systematic review of the literature. Pediatr. Pulmonol. 44 922-934 (2009).
153. Chaumais, M. et al. Fatal pulmonary fibrosis after rituximab administration. Pediatr. Nephrol. 24, 1753-1755 (2009)

154. Ergin, A. B., Fong, N. \& Daw, H. A. Rituximab induced bronchiolitis obliterans organizing pneumonia. Case Reports Med. http:// dx.doi.org/10.1155/2012/680431.

155. Albert, D. et al. Variability in the biological response to anti-CD20 B-cell depletion in systemic lupus erythematosus. Ann. Rheum. Dis. 67, 1724-1731 (2008).

156. Igarashi, T. et al. Factors affecting toxicity, response and progression-free survival in relapsed patients with indolent B-cell lymphoma and mantle cell lymphoma treated with rituximab: a Japanese phase II study. Ann. Oncol. 13, 928-943 (2002)

157. Lunardon, L. \& Payne, A. S. Inhibitory human antichimeric antibodies to rituximab in a patient with pemphigus. J. Allergy Clin. Immunol. 130, 800-803 (2012)

158. Looney, R. J. et al. B cell depletion as a nove treatment for systemic lupus erythematosus: a phase I/II dose-escalation trial of rituximab. Arthritis Rheum. 50, 2580-2589 (2004).

159. Davis, T. A. et al. Rituximab anti-CD20 monoclonal antibody therapy in non-Hodgkin's lymphoma: safety and efficacy of re-treatment. J. Clin. Oncol. 18, 3135-3143 (2000).

160. Robak, T. \& Robak, E. New anti-CD20 monoclonal antibodies for the treatment of B-cell lymphoid malignancies. BioDrugs 25, 13-25 (2011)

\section{Acknowledgements}

The authors would like to acknowledge the All India Institute of Medical Sciences, New Delhi, for supporting their research.

\section{Author contributions}

A. Sinha and A. Bagga contributed equally to researching data for the manuscript, writing, discussions of the content, review and/or editing of the manuscript before submission.

\section{Supplementary information}

Supplementary information is linked to the online version of the paper at www.nature.com/nrneph. 